Notre Dame Law School

NDLScholarship

Journal Articles

Publications

2015

\title{
The Hughes Court Docket Books: The Late Terms, $1937-1940$
}

Barry Cushman

Notre Dame Law School, bcushman@nd.edu

Follow this and additional works at: https://scholarship.law.nd.edu/law_faculty_scholarship

Part of the Supreme Court of the United States Commons

\section{Recommended Citation}

Barry Cushman, The Hughes Court Docket Books: The Late Terms, 1937-1940, 55 Am. J. Legal Hist. 361 (2015).

Available at: https://scholarship.law.nd.edu/law_faculty_scholarship/1300

This Article is brought to you for free and open access by the Publications at NDLScholarship. It has been accepted for inclusion in Journal Articles by an authorized administrator of NDLScholarship. For more information, please contact lawdr@nd.edu. 


\title{
The Hughes Court Docket Books: The Late Terms, 1937-1940
}

\author{
by BARRY CUSHMAN*
}

\section{ABSTRACT}

For many years, the docket books kept by a number of the justices of the Hughes Court have been held by the Office of the Curator of the Supreme Court. Yet the existence of these docket books was not widely known, and access to them was highly restricted. Recently, however, the Court adopted new guidelines designed to increase access to the docket books for researchers. This article offers the first-ever examination of the available docket book entries relevant to what scholars commonly regard as the major decisions of rendered during the late years of the Hughes Court, from the 1937 through the 1940 Terms. The decisions examined concern the Commerce Clause, the dormant Commerce Clause, substantive due process, equal protection, the general law, antitrust, labor relations, intergovernmental tax immunities, criminal procedure, civil rights, and civil liberties. The information in the docket books sheds new light on decisions such as Erie Railroad v. Tompkins, South Carolina State Highway Department v. Barnwell Bros., Inc., Lane v. Wilson, Railroad Commission of Texas v. Pullman, and United States v. Darby Lumber Co., and helps to explain how a nine-justice Court divided evenly on one of the issues in Coleman v. Miller. The docket books often reveal the justices' remarks at their conference deliberations over major cases, and illuminate many previously unknown changes in justices' positions between the conference votes and their final votes on the merits. Analysis of the voting data contained in the docket books also offers a contribution to two bodies of political science scholarship on judicial behavior:

\footnotetext{
*John P. Murphy Foundation Professor of Law, University of Notre Dame, bcushman@nd.edu. Thanks to Matthew Hofstedt, Devon Burge, Franz Jantzen, Lauren Morrell, Nikki Peronace, and Erin Huckle, all of the Office of the Curator of the Supreme Court of the United States, for their kind hospitality and splendid assistance with the Hughes Court docket books; to Jon Ashley, Dwight King, Kent Olson, Cathy Palombi, and Janet Rose for their cheerful and excellent research assistance; and to Michael Gilbert, John Harrison, Greg Mitchell, and participants in the Notre Dame Law School Faculty Colloquium for valuable comments and conversation.
} 
the literature on vote fluidity and unanimity norms in the Supreme Court, and the literature on the so-called "freshman effect" that some scholars have found exhibited by the Court's newest members. In particular, the analysis documents the prominent contribution that new justices, who disdained the Court's longstanding norm of acquiescence in the judgments of conference majorities, made to the substantial increase in the percentage of its cases that the Court decided by a divided vote. The analysis further reveals the significant part played by the last remnants of the Old Court in retarding what would become a precipitous decline in unanimity rates under Chief Justice Harlan Fiske Stone.

For many years, the docket books kept by a number of the Hughes Court justices have been held by the Office of the Curator of the Supreme Court. Yet the existence of these docket books was not widely known, and access to them was highly restricted. In April of 2014, however, the Court adopted new guidelines designed to increase access to the docket books for researchers. This article provides the first report on and analysis of the contents of all the docket books that the Curator's Office holds for the late Hughes Court, comprising the 1937-1940 Terms. Only one of the entries in these docket books has been examined and reported on before. ${ }^{1}$

This article canvasses the available docket book entries relevant to what scholars commonly regard as the major decisions of the late Hughes Court. ${ }^{2}$ This review includes seventy-six

\footnotetext{
1 Professor Daniel Ernst has reported on Justice Butler's entry for Morgan v. United States, 304 U.S. 1 (1938). See Daniel R. Ernst, Tocqueville's Nightmare: The Administrative State Emerges in America, 1900-1940, 186 n.115 (Oxford, New York, 2014) (citing Butler OT 1937 Docket Book). The existence of docket books of Justices Pierce Butler and Harlan Fiske Stone for several of the Terms of Chief Justice William Howard Taft's tenure was brought to the attention of the scholarly community by Robert Post, The Supreme Court Opinion as Institutional Practice: Dissent, Legal Scholarship, and Decisionmaking in the Taft Court, 85 Minn. L. Rev. 1267 (2001).

2 The cases selected as "major" or "salient" are those that regularly appear in scholarly treatments of the early Hughes Court. See, e.g., William G. Ross, The Chief Justiceship of Charles Evans Hughes, 1930-1941 (Univ. of South Carolina, Columbia, S.C., 2007); Michael E. Parrish, The Hughes Court: Justices, Rulings, Legacy (ABACLIO, 2002); G. Edward White, The Constitution and the New Deal (Harvard, Cambridge, Mass., 2000); Barry Cushman, Rethinking the New Deal Court: The Structure of a Constitutional Revolution (Oxford, New York, 1998); William E. Leuchtenburg,
} 
cases $^{3}$ concerning areas of law as diverse as the Commerce Clause, the dormant Commerce Clause, substantive due process, equal protection, the general law, antitrust, labor relations, intergovernmental tax immunities, criminal procedure, civil rights, and civil liberties. The information in the docket books sheds particularly fascinating new light on decisions such as Erie Railroad v. Tompkins, ${ }^{4}$ South Carolina State Highway Department v. Barnwell Bros., Inc., ${ }^{5}$ Lane v. Wilson, ${ }^{6}$ Coleman v. Miller, ${ }^{7}$ and United States v. Darby Lumber $\mathrm{Co}^{8}$ In addition, for these and the many other cases examined, this article also reports on whether a unanimous decision was also free from dissent at conference or became so only because

The Supreme Court Reborn: The Constitutional Revolution in the Age of Roosevelt (Oxford, New York, 1995); Alpheus Thomas Mason, Harlan Fiske Stone: Pillar of the Law (Viking, New York, 1956); Barry Cushman, The Secret Lives of the Four Horsemen, 83 Va. L. Rev. 559 (1997); Richard D. Friedman, Switching Time and Other Thought Experiments: The Hughes Court and Constitutional Transformation, $142 \mathrm{U}$. Pa. L. Rev. 1891 (1994). I have selected these cases not with an eye toward obtaining a representative sample of the Court's output, but instead because of the interest that previous scholars have shown in them. Scholars may differ concerning the inclusion or exclusion of particular cases from this category, and the statistical discussion in the Conclusion must be read with that caveat in mind. Notwithstanding such potential differences, however, my effort has been to select cases about which I believe there would be a broad measure of agreement. For other scholarship exploring judicial behaviour in "major" or "salient" cases, see Forrest Maltzman \& Peter J. Wahlbeck, Strategic Policy Considerations and Voting Fluidity on the Burger Court, 90 Am. Pol. Sci. Rev. 581, 589 (1996); Robert H. Dorff \& Saul Brenner, Conformity Voting on the United States Supreme Court, 54 J. Politics 762, 772, 773 (1992); Timothy M. Hagle \& Harold J. Spaeth, Voting Fluidity and the Attitudinal Model of Supreme Court Decision Making, 44 Western Political Quarterly 119, 124 (1991); Saul Brenner, Timothy Hagle, \& Harold J. Spaeth, Increasing the Size of Minimum Winning Coalitions on the Warren Court, 23 Polity 309 (1990); Saul Brenner, Timothy M. Hagle, \& Harold J. Spaeth, The Defection of the Marginal Justice on the Warren Court, 42 Western Political Quarterly 409 (1989); Saul Brenner, Fluidity on the Supreme Court: 1956-1967, 26 Am. J. Pol. Sci. 388, 389 (1982); Saul Brenner, Fluidity on the United States Supreme Court: A Reexamination, 24 Am. J. Pol. Sci. 526, 530 (1980); Ellliot E. Slotnick, Who Speaks for the Court? Majority Opinion Assignment from Taft to Burger, 23 Am. J. Pol. Sci. 60 (1979).

3 This count includes five cases decided per curiam. I exclude from this count National Licorice Co. v. NLRB, 309 U.S. 350 (1939), discussed infra, n. 55, because disparities in the conference records pose difficulties of classification.

\footnotetext{
${ }^{4} 304$ U.S. 64 (1938).

5303 U.S. 177 (1938).

6307 U.S. 268 (1939).

7307 U.S. 433 (1939).

8312 U.S. 100 (1941).
} 
one or more justices acquiesced in the judgment of their colleagues, as well as on whether non-unanimous decisions were divided by the same vote and with the same alliances at conference. The docket books also provide records of instances in which a case that initially was assigned to one justice was later reassigned to another. These records afford us some insight into the kinds of cases in which this tended to occur.

A review of the docket books of the late Hughes Court also makes possible two contributions to the political science literature on judicial behavior. The first is to the scholarship on vote fluidity and unanimity norms in the Supreme Court. It is widely agreed that the period from the Chief Justiceship of John Marshall through that of Charles Evans Hughes was characterized by a "norm of consensus," "marked by individual justices accepting the Court's majority opinions." 9 It is generally believed that this norm of consensus collapsed early in the Chief Justiceship of Harlan Fiske Stone, ${ }^{10}$ though some scholars have pointed to causes that antedate Stone's elevation to the center chair. ${ }^{11}$ Still others have suggested that there

9 Pamela C. Corley, Amy Steigerwalt, \& Artemus Ward, Revisiting the Roosevelt Court: The Critical Juncture from Consensus to Dissensus, 38 J. Sup. Ct. Hist. 20, 22 (2013); Mark S. Hurwitz \& Drew Noble Lanier, I Respectfully Dissent: Consensus, Agendas, and Policymaking on the U.S. Supreme Court, 1888-1999, 21 Review of Policy Research 429, 429 (2004); Lee Epstein, Jeffrey A. Segal, \& Harold J. Spaeth, The Norm of Consensus on the U.S. Supreme Court, 45 Am. J. Pol. Sci. 362, 376 (2001); Gregory A. Caldeira \& Christopher J.W. Zorn, Of Time and Consensual Norms in the Supreme Court, 42 Am. J. Pol. Sci. 874, 874-75 (1998); John P. Kelsh, The Opinion Delivery Practices of the United States Supreme Court 1790-1945, 77 Wash. U. L. Q. 137, 161-62 (1999); Thomas G. Walker, Lee Epstein, \& William J. Dixon, On the Mysterious Demise of Consensual Norms in the United States Supreme Court, $50 \mathrm{~J}$. Politics 361, 361-62 (1988).

${ }^{10}$ Herman C. Pritchett, The Roosevelt Court: A Study in Judicial Politics and Values, 1937-1947 40, 251 (Macmillan, New York, 1948) ("In 1941 divisive forces of some kind hit the Court full force"); Corley, Steigerwalt, \& Ward, $38 \mathrm{~J}$. Sup. Ct. Hist. at 47; Caldeira \& Zorn, 42 Am. J. Pol. Sci. at 874-75; Walker, Epstein, \& Dixon, 50 J. Politics 362; David Danelski, The Influence of the Chief Justice in the Decisional Process, in Joel B. Grossman \& Richard S. Wells, eds., Constitutional Law and Judicial Policy Making 175 (Wiley, New York, 1972).

${ }^{11}$ Compare Stephen C. Halpern \& Kenneth N. Vines, The Judges' Bill and the Role of the U.S. Supreme Court, 30 Western Political Quarterly 471, 481 (1977) (arguing that the enactment of the Judges' bill of 1925, which made the Court's docket almost entirely discretionary, increased the proportion of cases that were legally or politically salient and thus less likely to elicit acquiescence from colleagues inclined to disagree with the majority), with Walker, Epstein, \& Dixon, $50 \mathrm{~J}$. Politics at 365-66 (agreeing 
may have been "an earlier, more gradual change in norms" on the late Taft and Hughes Courts. ${ }^{12}$ Political scientists who have had access to the docket books of various justices serving on other Courts have demonstrated that much of the consensus achieved by the Court throughout its history has resulted from the decisions of justices who had dissented at conference to join the majority's ultimate disposition. A substantial body of literature shows that justices commonly have changed their votes between the conference and the final vote on the merits. ${ }^{13}$

that "it is possible that a discretionary docket may be one factor, and a necessary one at that, in maintaining high levels of conflict once such patterns are established," but disputing the contention that the 1925 statute was "the primary factor in the alteration of the Court's consensus norms," pointing out that "significant escalation in both the dissent and concurrence rates did not occur until almost fifteen years" after the dramatic increase in the discretionary share of the Court's docket); accord, Caldeira \& Zorn, $42 \mathrm{Am}$. J. Pol. Sci. at 875; Robert Post, The Supreme Court Opinion as Institutional Practice: Dissent, Legal Scholarship, and Decisionmaking in the Taft Court, 85 Minn. L. Rev. 1267, 1319-31 (2001) (rejecting the Halpern \& Vines hypothesis on the ground that unanimity rates in certiorari cases were higher than in those falling under the Court's mandatory jurisdiction, and offering alternative reasons, such as changes in external circumstances, in Court personnel, and in the quality of Taft's leadership, for the decline in unanimity on the late Taft Court).

${ }^{12}$ Caldeira \& Zorn, $42 \mathrm{Am}$. J. Pol. Sci. at 892. See also Aaron J. Ley, Kathleen Searles, \& Cornell W. Clayton, The Mysterious Persistence of Non-Consensual Norms on the U.S. Supreme Court, 49 Tulsa L. Rev. 99, 106 (2013) ("the proportion of unanimous decisions was declining prior to Stone's Chief Justiceship"); Marcus E. Hendershot, Mark S. Hurwitz, Drew Noble Lanier, \& Richard L. Pacelle, Jr., Dissensual Decision Making: Revisiting the Demise of Consensual Norms within the U.S. Supreme Court, 20 Political Research Quarterly 1, 8 (2012) ("the Court's norm of consensus was first challenged by growing levels of dissent in the later years of the Hughes Court"); David $M$. O'Brien, Institutional Norms and Supreme Court Opinions: On Reconsidering the Rise of Individual Opinions, in Cornell W. Clayton \& Howard Gillman, eds., Supreme Court Decision-Making: New Institutionalist Approaches 103 (Univ. of Chicago, Chicago, 1999) ("the demise of the norm of consensus preceded Stone's chief justiceship"); Stacia L. Haynie, Leadership and Consensus on the U.S. Supreme Court, 54 J. Politics 1158 (1992) (arguing that Stone consolidated a shift in behavioral expectations that began under Hughes). See also Kelsh, 77 Wash. U. L. Q. at 162 ("The most unusual thing about the nonunanimity rate for the 1864-1940 period is that the last ten years saw a sustained increase. This rate was to shoot up dramatically in the first years of the Stone Court, but the beginnings of the rise can be seen around 1930"); id. at 173 ("By the 1930 ... Justices had fully accepted the view that separate opinions had a legitimate role in the American legal system.") Compare Benjamin N. Cardozo, Law and Literature 34 (1931) (characterizing dissenters as "irresponsible").

${ }^{13}$ See, e.g., Epstein, Segal, \& Spaeth, 45 Am. J. Pol. Sci. 362 (Waite Court); Maltzman \& Wahlbeck, 90 Am. Pol. Sci. Rev. 581 (Burger Court); Dorff \& Brenner, 54 J. Politics 762 (Vinson, Warren, and Burger Courts); Hagle \& Spaeth, 44 Western 
Of the different types of vote fluidity between the conference vote and the final vote on the merits in major late Hughes Court cases, by far the most common was for a justice to move from a dissenting or passing vote to a vote with the ultimate majority. An examination of the docket books permits us to illuminate several features of this phenomenon: the major cases in which it occurred; how frequently it occurred in major cases; the frequency with which each of the justices did so; and the comparative success of early Hughes Court justices in preparing majority opinions that would either enlarge the size of the ultimate winning coalition or produce ultimate unanimity from a divided conference.

The second contribution concerns the behavior of newcomers to the Court. In 1958, Eloise C. Snyder published an article in which she concluded that new members of the Court tended initially to affiliate with a moderate, "pivotal clique" before migrating to a more clearly ideological liberal or conservative bloc. ${ }^{14}$ Seven years later, J. Woodford Howard argued that Justice Frank Murphy's first three terms on the Court were marked by a "freshman effect" characterized by an "instability" in his decision making that rendered the Justice "diffident to the point of indecisiveness." 15 These studies in turn spawned a literature on the "freshman" or "acclimation" effect for justices new to the Court. These studies generally characterize the freshman effect "as consisting of one or more of the following types of behavior: (1) initial bewilderment or disorientation, (2) assignment of a lower than average number of opinions to the new justices, and (3) an initial tendency on the part of the new justice to join a moderate block of justices." ${ }^{16}$ While some studies

Political Quarterly 119 (Warren Court); Brenner, Hagle, \& Spaeth, 23 Polity 309 (Warren Court); Brenner, Hagle, \& Spaeth, 42 Western Political Quarterly 409 (Warren Court); Brenner, 26 Am. J. Pol. Sci. 388 (Warren Court); Saul Brenner, Ideological Voting on the U.S. Supreme Court: A Comparison of the Original Vote on the Merits with the Final Vote, 22 Jurimetrics 287 (1982) (Vinson and Warren Courts); Brenner, 24 Am. J. Pol. Sci. 526 (Vinson and Warren Courts); J. Woodford Howard, Jr., On the Fluidity of Judicial Choice, 62 Am. Pol. Sci. Rev. 43 (1968) (Stone and Vinson Courts).

14 Eloise C. Snyder. The Supreme Court as a Small Group, 3 Social Forces 232, 238 (1958).

${ }^{15}$ Woodford Howard, Justice Murphy: The Freshman Years, 18 Vand. L. Rev. 473, 474, 476, 477, 484, 488, 505 (1965).

16 Timothy M. Hagle, "Freshman Effects" for Supreme Court Justices, 37 Am. J. Pol. Sci. 1142, 1142 (1993). See also Leigh Anne Williams, Measuring Internal Influence on the Rehnquist Court: An Analysis of Non-Majority Opinion Joining Behavior, 
have confirmed the existence of some feature or another of the freshman effect, ${ }^{17}$ others have cast significant doubt on the hypothesis, maintaining that it is either non-existent or confined to limited circumstances. ${ }^{18}$ Studies of the freshman period for

68 Ohio St. L. J. 679, 718-19 (2007); Saul Brenner \& Timothy M. Hagle, Opinion Writing and Acclimation Effect, 18 Pol. Behav. 235 (1996); Paul C. Arledge \& Edward W. Heck, A Freshman Justice Confronts the Constitution: Justice O'Connor and the First Amendment, 45 Western Pol. Q. 761, 761-62 (1992); Edward V. Heck \& Melinda Gann Hall, Bloc Voting and the Freshman Justice Revisited, 43 J. Politics 852, 853-54 (1981); Elliot E. Slotnick, Judicial Career Patterns and Majority Opinion Assignment on the Supreme Court, $41 \mathrm{~J}$. Politics 640, 641 (1979).

17 See, e.g., Lee Epstein, Kevin Quinn, Andrew D. Martin, \& Jeffrey E. Segal, On the Perils of Drawing Inferences about Supreme Court Justices from Their First Few Years of Service, 91 Judicature 168, 179 (2008) (finding evidence of ideological instability in the merits voting of "virtually all" freshman justices); Mark S. Hurwitz \& Joseph V. Stefko, Acclimation and Attitudes: "Newcomer" Justices and Precedent Conformance on the Supreme Court, 57 Pol. Res. Q. 121 (2004) (finding freshman effect with respect to conformity to precedent); Charles R. Shipan, Acclimation Effects Revisited, 40 Jurimetrics 243 (2000) (finding evidence of ideological instability in the merits voting of some but not most freshmen justices on the Warren and Burger Courts); Sandra L. Wood, Linda Camp Keith, Drew Noble Lanier, \& Ayo Ogundele, "Acclimation Effects" for Supreme Court Justices: A Cross-Validation, 1888-1940, 42 Am. J. Pol. Sci. 690, 694 (1998) (finding "some evidence of an acclimation effect for at least some of the justices" with respect to ideological instability in merits voting); Brenner \& Hagle, 18 Pol. Behav. 235 (finding freshman effect with respect to opinion output); Timothy M. Hagle, A New Test for the Freshman Effect, 21 Southeastern Pol. Rev. 289 (1993) (finding evidence of ideological instability in the merits voting of some freshman justices on the Burger and Rehnquist Courts); Hagle, $37 \mathrm{Am}$. J. Pol. Sci. 1142 (finding evidence of ideological instability in the merits voting of some justices joining the Court between 1953 and 1989); S. Sidney Ulmer, Toward a Theory of Sub-Group Formation in the United States Supreme Court, $27 \mathrm{~J}$. Politics 133,151 (1965) (finding some evidence of freshman effect in bloc voting for justices joining the Court between 1946 and 1961).

${ }^{18}$ See, e.g., Paul J. Wahlbeck, James F. Spriggs II, \& Forrest Maltzman, The Politics of Dissents and Concurrences on the U.S. Supreme Court, 27 American Politics Quarterly 488, 503-04 (1999) ("Contrary to the freshman effect hypothesis, freshman justices are no less likely to join or author a concurring or dissenting opinion than their more senior colleagues"); Richard Pacelle \& Patricia Pauly, The Freshman Effect Revisited: An Individual Analysis, 17 Am. Rev. Politics. 1, 6, 15 (1996) (finding no freshman effect with respect to ideological instability in merits votes in the aggregate, and "only limited evidence" of such an effect with respect to individual justices joining the Court between 1945 and 1988); Terry Bowen, Consensual Norms and the Freshman Effect on the United States Supreme Court, 76 Soc. Sci. Q. 222, 227 (1995) (finding no freshman effect for separate opinion writing on the Hughes and Taft Courts, but finding such a freshman effect during the 1941-1992 period); Terry Bowen \& John M. Scheb II, Freshman Opinion Writing on the U.S. Supreme Court, 1921-1991, 76 Judicature 239 (1993) (finding no freshman effect with respect to opinion assignments); Robert L. Dudley, The Freshman Effect and Voting 
individual justices on the whole have not lent much support to the hypothesis. ${ }^{19}$

Professor Howard suggested that the freshman effect might also be manifested by a tendency of new justices to change their votes between the conference vote and the final vote on the merits. Howard listed a number of considerations that might prompt a justice to shift ground in this manner, but first among them were "unstable attitudes that seem to have resulted from the process of assimilation to the Court." For instance, he remarked, "Justice Cardozo, according to one clerk's recollection of the docket books... frequently vot[ed] alone in conference before ultimately submerging himself in a group opinion." 20 Howard reported that

Alignments: A Reexamination of Judicial Folklore, 21 Am. Politics Q. 360 (1993) (finding no freshman effect with respect to bloc voting even when using Snyder's data); Terry Bowen \& John M. Scheb II, Reassessing the "Freshman Effect": The Voting Bloc Alignment of New Justices on the United States Supreme Court, 1921-90, 15 Pol. Behav. 1 (1983) (finding no freshman effect with respect to bloc voting); Heck \& Hall, 43 J. Politics 852 (finding very little evidence of a freshman effect in bloc voting on the Warren and Burger Courts); Slotnick, 41 J. Politics 640 (finding no freshman effect with respect to opinion assignments). For efforts to explain the divergences in scholarly findings, see Hagle, 21 Southeastern Pol. Rev. 289; Hagle, 37 Am. J. Pol. Sci. 1142; Albert P. Melone, Revisiting the Freshman Effect Hypothesis: The First Two Terms of Justice Anthony Kennedy, 74 Judicature 6, 13 (1990); Heck \& Hall, 43 J. Politics at 859-60.

${ }^{19}$ See, e.g., Thomas R. Hensley, Joyce A. Baugh, \& Christopher E. Smith, The FirstTerm Performance of Chief Justice John Roberts, 43 Idaho L. Rev. 625, 631 (2007) (finding no freshman effect with respect to bloc voting); Christopher E. Smith \& S. Thomas Read, The Performance and Effectiveness of New Appointees to the Rehnquist Court, 20 Ohio N. U. L. Rev. 205 (1993) (finding a freshman effect with respect to Justice Souter but not with respect to Justice Thomas); Arledge \& Heck, 45 Western Pol. Q. 761 (finding no freshman effect); Melone, 74 Judicature 6 (finding a freshman effect only with respect to majority opinion assignments); Thea F. Rubin \& Albert P. Melone, Justice Antonin Scalia: A First Year Freshman Effect?, 72 Judicature 98 (1988) (finding a freshman effect only with respect to majority opinion assignments); John M. Scheb II \& Lee W. Ailshie, Justice Sandra Day O'Connor and the Freshman Effect, 69 Judicature 9 (1985) (finding evidence of a freshman effect only with respect to majority opinion assignments in her first Term); Edward V. Heck, The Socialization of a Freshman Justice: The Early Years of Justice Brennan, 10 Pac. L. J. 707, 714-16, 722-25 (1979) (finding little evidence of a freshman effect).

${ }^{20}$ Howard, Jr., $62 \mathrm{Am}$. Pol. Sci. Rev. at 45 . The clerk to whom Howard referred was Paul Freund, who clerked for Justice Brandeis during the 1932 Term. See Paul Freund, A Tale of Two Terms, 26 Ohio St. L. J. 225, 227 (1965) ("I was struck in the 1932 Term with the number of occasions on which what came down as unanimous opinions had been far from that at conference. I had access to the docket book which the Justice kept as a record of the conference vote - these books are 
Justice Murphy exhibited "a similar instability" during his freshman years on the Court. ${ }^{21}$ Subsequent studies from the Vinson, Warren, and Burger Court docket books have produced divergent conclusions with respect to this reputed feature of the freshman effect. ${ }^{22}$

Though there is no agreed-upon period of judicial tenure during which to test for the freshman effect, the periods tested in the literature have ranged from one to five years. ${ }^{23}$ Between 1937 and 1940 Franklin Roosevelt appointed five new justices to the Supreme Court: Hugo Black, Stanley Reed, Felix Frankfurter, William O. Douglas, and Frank Murphy. A review of the voting behavior of these newcomers to the Court does not disclose any appreciable freshman effect with respect to voting fluidity. Instead, one finds that in the major cases examined here, these justices were among the least likely to change their positions between the conference vote and the final vote on the merits.

This article proceeds as follows. Section I introduces the justices of the late Hughes Court and describes the contents of their

destroyed at the end of each term - and I was enormously impressed with how many divisions there were that did not show up in the final vote. I was impressed with how often Justice Cardozo was in a minority, often of one, at conference, but did not press his position.")

21 Howard, Jr., 62 Am. Pol. Sci. Rev. at 45.

22 Compare Maltzman \& Wahlbeck, 90 Am. Pol. Sci. Rev. at 589 (finding that "freshmen justices are significantly more likely to switch than are their more senior colleagues"), Saul Brenner, Another Look at Freshman Indecisiveness on the United States Supreme Court, 16 Polity 320 (1983) (finding that between the 1946 and 1966 Terms freshman justices exhibited on average greater fluidity between the conference vote and the final votes on the merits than did senior justices, and that this fluidity tended to diminish between a justice's first and fourth terms on the Court), and Dorff \& Brenner, $54 \mathrm{~J}$. Politics at 767, 769-71 (finding that freshman justices were "more likely to be uncertain regarding how to vote at the original vote on the merits and more likely to be influenced by the decision of the majority at the final vote") with Hagle \& Spaeth, 44 Western Political Quarterly 119 (finding that the voting fluidity of freshman justices on the Warren Court did not differ significantly from that of their more senior colleagues, and that the voting fluidity of such freshman justices had not diminished by their third and fourth Terms on the Court). See also Timothy R. Johnson, James F. Spriggs II, \& Peter J. Wahlbeck, Passing and Strategic Voting on the U.S. Supreme Court, 39 Law \& Society Rev. 349, 369 (2005) (finding that freshman justices on the Burger Court did not pass more frequently than their senior colleagues).

${ }^{23}$ Brenner \& Hagle, 18 Pol. Behav. at 239. Professor Howard, the first to identify the phenomenon, suggested that the freshman period was typically about three years. Howard, Jr., 62 Am. Pol. Sci. Rev. at 45. 
surviving docket books. Section II discusses the major decisions handed down by the late Hughes Court during the 1937-1940 terms. Section III examines the reassignment practices of the late Hughes Court. Section IV concludes.

\section{THE LATE HUGHES COURT JUSTICES AND THEIR DOCKET BOOKS}

In contrast to the early Hughes Court, the late Hughes Court was notable for its significant and frequent changes in personnel. Justice Willis Van Devanter retired on June 2,1937, ${ }^{24}$ and was replaced by Justice Hugo Black on August 18 of that year. ${ }^{25}$ Justice George Sutherland stepped down on January $18,1938,{ }^{26}$ and Justice Stanley Reed took seat on January $31 .{ }^{27}$ Justice Benjamin N. Cardozo became ill in December of 1937, and did not sit for any cases thereafter. ${ }^{28} \mathrm{He}$ died on July $8,1938,{ }^{29}$ and was replaced by Justice Felix Frankfurter on January 30,1939. ${ }^{30}$ Justice Louis D. Brandeis retired on February 13, 1939, ${ }^{31}$ and was succeeded by Justice William O. Douglas two months later on April 17. ${ }^{32}$ Illness prevented Justice Pierce Butler from attending any of the Court's sessions during the 1939 Term, and he did not take part in any of that Term's cases. ${ }^{33}$ He died on November 16 of that year, ${ }^{34}$ and Justice Frank Murphy assumed his seat on February 5, 1940..$^{35}$ And though Justice James Clark McReynolds retired on February 1, 1941, ${ }^{36}$ Justice James Byrnes did not replace him until July 8 of that year ${ }^{37}$-just over a

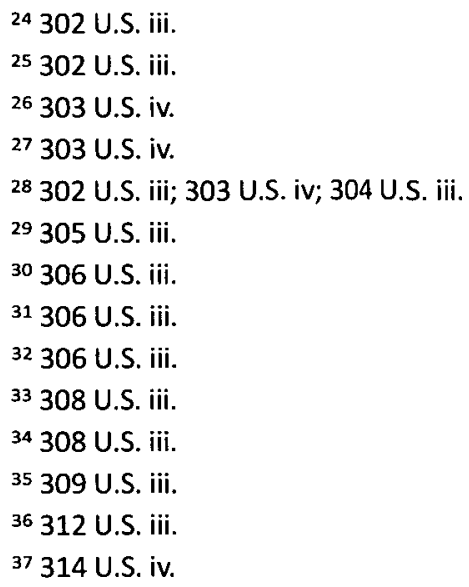


week after Hughes's retirement on July $1 .^{38}$ Of the justices who sat with Hughes during the tumultuous 1936 Term, only Harlan Fiske Stone and Owen Roberts remained on the Court for the remainder of Hughes's tenure as Chief Justice.

The Office of the Curator has in its collection the docket books of six of the late Hughes Court justices. Unfortunately, the docket books of Chief Justice Hughes and Justice Sutherland do not appear to have survived, and during this period Justice McReynolds burned his docket books at the conclusion of each Term. ${ }^{39}$ However, the Curator's collection does contain a nearly complete run of Pierce Butler's docket books, including the 1937 through 1939 Terms. Butler's docket book for the 1939 Term regrettably is not of much use, as the Justice became ill and died rather early in the Term, and did not participate in any of the Term's cases. ${ }^{40}$ This gap is especially unfortunate, because Butler's docket books provide not only a record of conference votes, but also a remarkably rich set of notes on conference discussions. These notes corroborate numerous accounts of Hughes's conduct of the Court's conferences, ${ }^{41}$ at which the Chief Justice would begin with a masterful presentation of the facts and issues in each case and a statement of his own views of how those issues should be resolved. The justices would next present their own views in descending order of seniority, and would finally cast their votes in ascending order of seniority, with Hughes voting last. Butler's notes therefore often consist principally of the Chief Justice's remarks, which help to compensate for the fact that Hughes's docket books and Court papers have not survived.

The Curator's collection likewise contains a complete run of the docket books of Justice Stone, from the 1937 through the 1940 Terms. The Stone docket books contain records of the conference votes in most cases, and occasionally some notes on the remarks made by colleagues during conference discussions. Unfortunately, Stone's handwriting is very difficult to decipher, so the content of these notes too often remains obscure. The collection also has

\footnotetext{
38313 U.S. iii.

${ }^{39}$ Dennis J. Hutchinson \& David J. Garrow, eds., The Forgotten Memoir of John Knox 84 (Univ. of Chicago, Chicago, 2002).

40308 U.S. iii.

${ }^{41}$ See, e.g., the discussion and sources collected in Ross at 219-21.
} 
nearly a complete run of the docket books for Owen Roberts, including the 1937, 1938, and 1940 Terms. Unfortunately, the collection does not contain a docket book for Roberts for the 1939 Term. It does not appear that this docket book has survived. The Roberts docket books similarly contain records of the conference votes in most cases, along with an occasional but none-too-frequent note on conference discussions.

Professor Paul Freund, who clerked for Justice Brandeis during the 1932 Term, reported that for most of his judicial career the Justice destroyed his docket books at the end of each Term. ${ }^{42}$ Brandeis discontinued this practice toward the end of his tenure, however, and as a result the Curator's collection holds his docket books for the 1937 and 1938 Terms. These books contain records of the conference votes in most cases, along with occasional notes on conference discussions. Brandeis's handwriting is more legible than Stone's, but still sometimes difficult to make out. Regrettably, in some instances the Justice's notes on the conference discussion are obscured by a pasted-over, typed account of the ultimate disposition. Unlike his colleagues, Brandeis systematically recorded the dates on which cases were taken up in conference. The entries in the docket book for the 1938 Term are incomplete because of the Justice's retirement in February of 1939. ${ }^{43}$

The collection's holdings of docket books for the newer justices of the late Hughes Court are comparatively small. There is a 1939 Term docket book for Frankfurter, but it contains no entries. There are also Murphy docket books for the 1939 and 1940 Terms, but the 1939 docket book contains no records of conference votes or deliberations for cases decided that Term. This leaves Stone's as the only informative 1939 docket book in the Curator's collection. Fortunately, Stone's entries can be corroborated and clarified by Justice Douglas's docket books for the 1938 through 1940 Terms, which are among those housed with his other papers in the Manuscript Division of the Library of Congress. In addition, Justice Reed's docket books for the 1937 through 1940 Terms are among those held with his papers at the M. I. King Library at the University of

42 Chief Justice William H. Rehnquist and Professor Paul A. Freund, "A Colloquy," Proceedings of the Forty-Ninth Judicial Conference of the District of Columbia Circuit (May 24, 1989), reprinted in 124 F.R.D. 241, 347 (1988).

${ }^{43} 306$ U.S. iii. 
Kentucky. Reed's docket books also provide a useful check on those of his colleagues, though unfortunately there were several cases decided during the 1939 and 1940 Terms for which Reed did not record the conference vote..$^{44}$

In discussing the post-conference voting behaviors of the Hughes Court justices, I will be using several defined terms. I shall use the term acquiescence to denote instances in which a justice who either dissented or passed at conference ultimately joined in the majority's disposition. ${ }^{45}$ In other words, acquiescence denotes instances in which a justice who was not with the majority at conference moved toward the majority. I will refer to movements from dissent at conference to the majority in the final vote on the merits ${ }^{46}$ as instances of strong acquiescence; movements from a passing vote at conference to the majority in the final vote on the merits as instances of weak acquiescence. ${ }^{47}$ of course, such movement might have occurred either because the justice in question became persuaded that the majority was correct, or because, though remaining unpersuaded, he elected to go along with the majority for the sake of some other consideration such as collegiality or public perception. ${ }^{48}$ The information contained in the docket books does not enable us to discriminate between these two

44 Each of these docket books in the Curator's collection remained in the Supreme Court building after the respective justice either retired or died while in office. It is not known why these volumes were retained, nor why not all of the sets of docket books are complete. In 1972 all of the "historic" docket books held in the Supreme Court building were boxed up by the Court's Marshal at the order of Chief Justice Warren Burger, and were later transferred to the Curator's Office. Email communication from Matthew Hofstedt, Associate Curator, Supreme Court of the United States, August 26, 2014.

45 This is also sometimes referred to as "conformity voting," see, e.g., Dorff \& Brenner, $54 \mathrm{~J}$. Politics at 763; or "minority-majority voting," see, e.g., Saul Brenner \& Robert H. Dorff, The Attitudinal Model and Fluidity Voting on the United States Supreme Court: A Theoretical Perspective, 4 J. Theoretical Politics 195, 197 (1992).

${ }^{46} \mathrm{I}$ borrow this term from Brenner, 22 Jurimetrics at 287. What Professor Brenner calls the "original vote on the merits" I refer to as the "conference vote."

47 These two terms are adapted from Saul Brenner, Fluidity on the Supreme Court: 1956-1967, 26 Am. J. Pol. Sci. 388, 388 (1982) and Saul Brenner, Fluidity on the United States Supreme Court: A Reexamination, 24 J. Pol. Sci. 526, 527 (1980) (referring to such movements as "strong fluidity" and "weak fluidity," respectively.)

${ }^{48}$ See, e.g., Brenner \& Dorff, 4 J. Theoretical Politics at 200 (concluding that justices acquiesce "for non-attitudinal reasons, including small-group reasons"); Howard, Jr., 62 Am. Pol. Sci. Rev. at 45 (same). 
possibilities, and therefore I shall not attempt to do so here. I will use the term non-acquiescence to denote instances in which a justice who dissented at conference remained steadfast in his opposition to the majority's disposition. In cases of non-acquiescence, there was no post-conference change in the vote of the justice in question. Finally, I will use the term defection to denote instances in which a justice who was either member of the conference majority or passed at conference later dissented from the published opinion. ${ }^{49}$ In other words, defection denotes instances in which the justice in question resisted what Dean Robert Post has called the "norm of acquiescence" 50 by moving away from the majority. Again, I will refer to movements from the majority at conference to dissent in the final vote on the merits as instances of strong defection; movements from a passing vote at conference to the dissent in the final vote on the merits as instances of weak defection..$^{51}$

\section{THE CASES}

\section{Unanimous Decisions with No Vote Changes}

Though most of the major unanimous decisions of the late Hughes Court involved post-conference acquiescence, there were some that produced unanimity from the outset. It is noteworthy that many though not all of these cases were decided after McReynolds, the last of the Four Horsemen to leave the bench, retired from the Court in early 1941 . Such was the case in the leading federal courts decision of Klaxon v. Stentor Electric Manufacturing Co., Inc., ${ }^{52}$ which held that a federal court exercising diversity jurisdiction must apply the conflict of laws principles of the state in which

${ }^{49}$ This is also sometimes referred to as "counterconformity voting," see, e.g., Dorff \& Brenner, $54 \mathrm{~J}$. Politics at 763; or "majority-minority voting," see, e.g., Brenner \& Dorff, 4 J. Theoretical Politics at 197.

50 Post, 85 Minn. L. Rev. at 1309.

51 Id. There also are instances in which a docket book entry does not record a vote for a particular justice. Often that was because the justice was absent from the conference, and where that was the case, I do not treat that justice as having engaged in any of the defined voting behaviors.

52313 U.S. 487 (1941). 
it sits. ${ }^{53}$ In the still-divisive domain of political economy, the leading such example is Olsen v. Nebraska, which upheld state regulation of fees charged by employment agencies. ${ }^{54}$ Before his departure, however, McReynolds did agree from the outset with a few unanimous political economy decisions. Among these were judgments upholding National Labor Relations Board (NLRB) rulings ordering companies to cease commission of unfair labor practices, ${ }^{55}$ and Pittman v. Home Owners' Loan Corp. ${ }^{56}$ which unanimously invalidated a Maryland state tax on mortgages as applied to a mortgage tendered for record by the federal Home Owners' Loan

53 Stone OT 1940 Docket Book; Roberts OT 1940 Docket Book; Douglas OT 1940 Docket Book; Murphy OT 1940 Docket Book. Reed OT 1940 Docket Book contains no record of the conference vote.

54313 U.S. 236 (1941); Stone OT 1940 Docket Book; Roberts OT 1940 Docket Book; Douglas OT 1940 Docket Book; Murphy OT 1940 Docket Book. Reed OT 1940 Docket Book contains no record of the conference vote.

55 See, e.g., NLRB v. Pacific Greyhound Lines, Inc., 303 U.S. 272 (1938), and NLRB v. Pennsylvania Greyhound Lines, Inc., 303 U.S. 261 (1938) (supporting NLRB rulings ordering interstate transit companies to cease commission of unfair labor practices) (Reed and Cardozo took no part); Stone OT 1937 Docket Book; Butler OT 1937 Docket Book; Roberts OT 1937 Docket Book; Brandeis OT 1937 Docket Book. In each case Stone wrote "out" in Reed's voting column and a question mark next to Butler's vote with the majority. Butler's entry has no record of the vote in Pacific Greyhound, writing only "Little difference from 413 [Pennsylvania Greyhound]." In Pennsylvania Greyhound, Butler noted that he voted with the majority "tentatively." Reed OT 1937 Docket Book simply records for each case, "No participation." It appears that McReynolds harbored unexpressed reservations in each of these cases. On his return of Stone's opinion in Pennsylvania Greyhound he wrote, "I cannot agree but don't care to pursue the matter further." Justice McReynolds, Return of NLRB v. Pennsylvania Greyhound Lines, Inc., Box 63, Harlan Fiske Stone MSS, Manuscript Division, Library of Congress. On his return in Pacific Greyhound, McReynolds simply wrote, "As in No. 413 [Pennsylvania Greyhound]." Justice McReynolds, Return of NLRB v. Pacific Greyhound Lines, Inc., Box 63, Harlan Fiske Stone MSS, Manuscript Division, Library of Congress.

Also possibly in this category is National Licorice Co. v. NLRB, 309 U.S. 350 (1939) (affirming NLRB ruling ordering company to cease unfair labor practices, with Black and Douglas voting to affirm but without modification of the order) (Murphy took no part). Stone OT 1939 Docket Book records the conference vote as unanimous, but Douglas OT 1939 Docket Book records McReynolds as passing. Reed OT 1939 Docket Book records Roberts and Murphy as passing, and all others voting to affirm. It appears likely that Douglas correctly recorded McReynolds's position. On his return of Stone's opinion McReynolds wrote, "I do not care to say anything." Justice McReynolds, Return of National Licorice Co. v. NLRB, Box 65, Harlan Fiske Stone MSS, Manuscript Division, Library of Congress.

56308 U.S. 21 (1939). 
Corporation. ${ }^{57}$ And in United States v. Powers, ${ }^{58}$ the Court unanimously sustained indictments under the Connally Hot Oil Act, which prohibited interstate shipment of oil "produced or withdrawn from storage in excess of the amount permitted... by any State law." 59

A mixed bag of civil rights and civil liberties decisions also were unanimous at both the conference vote and the final vote on the merits. Breedlove v. Suttles ${ }^{60}$ upheld Georgia's requirement that voters pay a poll tax. ${ }^{61}$ By contrast, Hale v. Kentucky ${ }^{62}$ was a unanimous per curiam decision reversing a murder conviction on the ground that African-Americans had been systematically excluded from the grand jury. ${ }^{63}$ Mitchell $v$. United States ${ }^{64}$ unanimously held that the consignment of an African-American passenger (who happened to be a member of the U.S. House of Representatives) to a segregated second-class rail car when he offered to pay for available first-class accommodations violated the Interstate Commerce Act. ${ }^{65}$ Cox v. New Hampshire ${ }^{66}$ unanimously affirmed convictions of Jehovah's Witnesses for violation of a state statute prohibiting a "parade or procession" upon a public street without a special license. ${ }^{67}$ Finally, United States v. Miller ${ }^{68}$

57 Stone OT 1939 Docket Book; Douglas OT 1939 Docket Book. Reed OT 1939 Docket Book contains no record of the conference vote.

58307 U.S. 214 (1939).

59 Roberts OT 1938 Docket Book does not record a vote for Butler, but the Stone OT 1938 Docket Book, the Butler OT 1938 Docket Book, and the Douglas OT 1938 Docket Book each record the April 22 vote as unanimous and Butler as in the majority. Reed OT 1938 Docket Book simply records, "All reverse."

60302 U.S. 277 (1937).

61 Stone OT 1937 Docket Book; Roberts OT 1937 Docket Book; Brandeis OT 1937 Docket Book. Butler recorded in his Docket Book, "19 Am. not involved."

62303 U.S. 613 (1938).

63 Stone OT 1937 Docket Book; Butler OT 1937 Docket Book; Roberts OT 1937 Docket Book; Brandeis OT 1937 Docket Book; Reed OT 1937 Docket Book. Both Brandeis and Cardozo were absent from the conference, and Cardozo took no part in the decision.

64313 U.S. 80 (1941).

65 Stone OT 1940 Docket Book; Roberts OT 1940 Docket Book; Reed OT 1940 Docket Book; Douglas OT 1940 Docket Book; Murphy OT 1940 Docket Book.

66312 U.S. 569 (1941).

67 Stone OT 1940 Docket Book; Roberts OT 1940 Docket Book; Reed OT 1940 Docket Book; Douglas OT 1940 Docket Book; Murphy OT 1940 Docket Book.

68307 U.S. 174 (1939). 
unanimously upheld provisions of the National Firearms Act over Tenth and Second Amendment objections. The vote at the conference was unanimous, with the ailing Chief Justice not present. ${ }^{69}$

\section{Unanimous Decisions with Vote Changes}

There were several important decisions in which the late Hughes Court forged unanimity in the wake of a divided conference vote. Many of these involved significant questions of constitutional political economy. In two cases handed down in early 1938, for example, the Court unanimously held that power companies lacked standing to challenge grants and loans made by the Emergency Relief Administration of Public Works to assist in the construction of electrical distribution systems. In the conference votes in Alabama Power Co. v. Ickes ${ }^{70}$ and Duke Power Co. v. Greenwood County, ${ }^{71}$ however, McReynolds had passed. ${ }^{72}$ Stone records Black, who ultimately concurred in the result in both cases, as arguing that there was "No standing" in Alabama Power. ${ }^{73}$ Butler records Hughes asserting that there was "no coercion" involved in the building of the systems, though the "competition will have serious effect." Brandeis agreed with Hughes, and Sutherland stated that the company "Has no standing to complain." McReynolds

${ }^{69}$ Stone OT 1938 Docket Book; Butler OT 1938 Docket Book; Roberts OT 1938 Docket Book; Reed OT 1938 Docket Book. Douglas took no part in the decision. Miller was argued on March 30 and decided on May 15. 307 U.S. 174. Hughes was absent from the Court due to illness from March 4 to April 15, and therefore was not present for the April 1 Miller conference. See Hughes Attends Court Conference, Wash. Post, April 16, 1939, p. 3 ("Chief Justice Hughes attended a conference of the Supreme Court justices yesterday. It was his first visit to the Court since he became ill with grippe March 4.") In Clason v. Indiana, 306 U.S. 439 (1939), the Court unanimously upheld an animal disposal licensing statute against a dormant Commerce Clause challenge. The conference vote was similarly unanimous, though the ailing and hence absent Hughes did not vote. Stone OT 1938 Docket Book; Butler OT 1938 Docket Book; Roberts OT 1938 Docket Book; Reed OT 1938 Docket Book. Brandeis was absent from the conference, and his docket book contains no record of the conference vote. Brandeis OT 1938 Docket Book. Butler's record contains the notation, "Qualified concurrence. Health measure."

70302 U.S. 464 (1938).

71302 U.S. 485 (1938).

72 Stone OT 1937 Docket Book; Butler OT 1937 Docket Book; Roberts OT 1937 Docket Book; Brandeis OT 1937 Docket Book.

${ }^{73}$ Stone OT 1937 Docket Book. 
remarked "is a fraud from bot[tom] to top." 74 One might infer from these comments that McReynolds's ultimate vote with the majority was an instance of acquiescence rather than conversion.

In South Carolina State Highway Department v. Barnwell Bros., Inc., ${ }^{75}$ a major dormant Commerce Clause decision, the Court unanimously upheld a state highway safety statute prohibiting certain truck transportation from entering the state. At the conference vote, however, Brandeis cast a dissenting ballot. ${ }^{76}$ Butler records Hughes as stating, "Uniformity not required by ICC [interstate Commerce Clause]. One state can't decide for another. Congress has not taken over this field. But as there is a burden, this state can't go beyond its necessities. But that is not a judicial question. State legislative discretion." Butler records McReynolds, Sutherland, Butler, and Stone as voicing agreement with Hughes, but Brandeis as arguing "No. bad use of highway.... Finding that caused interruption of great inter[state] com[merce] not justified." 77 On his return of Stone's opinion, however, Brandeis wrote, "A job admirably done. There is so much in the opinion that is wise and well said that, despite some lingering doubts, I agree - and congratulate you."78

United States v. Lowden ${ }^{79}$ is interesting primarily for what reveals about the status of the 1935 case of Railroad Retirement Board $v$. Alton Railroad Co., ${ }^{80}$ in which Roberts had written an opinion joined by the Four Horsemen striking down the Railroad Retirement Act of 1934. Lowden unanimously upheld an Interstate Commerce Commission (ICC) order permitting one railroad company to lease its facilities to another railway company. ${ }^{81}$ Because the ICC

74 Butler OT 1937 Docket Book.

75303 U.S. 177 (1938). Cardozo and Reed took no part in the decision.

${ }^{76}$ Stone OT 1937 Docket Book; Roberts OT 1937 Docket Book; Brandeis OT 1937 Docket Book. Brandeis has an illegible notation next to Black's vote.

77 Butler OT 1937 Docket Book. Stone also records Hughes as saying, "Uniformity not required. One state can't decide for another. State may not [four illegible words], but that a matter for legislative not judicial judgment." Stone OT 1937 Docket Book.

78 Justice Brandeis, Return of South Carolina State Highway Department v. Barnwell Bros., Inc., Box 63, Harlan Fiske Stone MSS, Manuscript Division, Library of Congress.

79308 U.S. 225 (1939). Butler took no part in the decision.

80295 U.S. 330 (1935).

81308 U.S. at 238. 
recognized that the lease would result in the discharge or transfer of several employees of the lessor railroad, the order conditioned the agency's approval of the lease agreement on the payment of partial compensation to such employees for any losses they might suffer as a consequence. ${ }^{82}$ The trustees in bankruptcy of the railroads in question invoked Alton in support of the claim that the order was not within the congressional power to regulate interstate commerce and worked a denial of due process. Stone's majority opinion upholding the order dismissed these objections. ${ }^{83}$ "[N]otwithstanding what was said" in Alton, Stone maintained, the order was rationally related to the protection of the public interest as defined by the statute, and that was reason enough to uphold it. ${ }^{84}$ Stone later wrote privately to Robert Jackson that the Lowden would "serve as both a footnote and a headstone" for Alton. ${ }^{85}$ Yet the unanimity of the published opinion masked significant divisions at conference. There the vote was 5-3, with the ailing Butler absent and McReynolds and Roberts dissenting along with Hughes. ${ }^{86}$ On his return of the opinion McReynolds wrote, "Sorry, this seems to me both wrong and unfortunate." 87 In the end, however, each of the conference dissenters suppressed his disagreement with the majority's judgment. As Roberts wrote on his return of Stone's opinion, "I voted the other way, but am not disposed to say anything; and unless someone else writes, I shall acquiesce." ${ }^{\prime 88}$

In the landmark Commerce Clause decision of United States $v$. Darby, ${ }^{89}$ the Court unanimously upheld the Fair Labor Standards

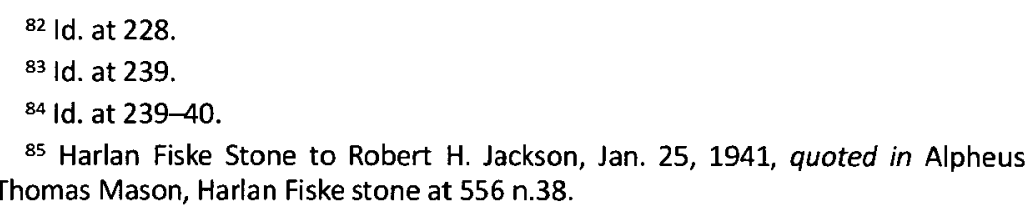

${ }^{86}$ Stone OT 1939 Docket Book; Reed OT 1939 Docket Book; Douglas OT 1939 Docket Book. It is sometimes forgotten that Hughes, who wrote the dissenting opinion in Alton, agreed that at least one of the provisions of the Railroad Retirement Act of 1934 violated the Due Process Clause. See 295 U.S. at 389 (Hughes, C.J., dissenting).

87 Justice McReynolds, Return of United States v. Lowden, Box 65, Harlan Fiske Stone MSS, Manuscript Division, Library of Congress.

88 Justice Roberts, Return of United States v. Lowden, Box 65, Harlan Fiske Stone MSS, Manuscript Division, Library of Congress.

${ }^{89} 312$ U.S. 100 (1941). 
Act of 1938. At the conference, however, Hughes and McReynolds passed. ${ }^{90}$ The notes of the conference discussion taken by Douglas and Murphy reveal that Hughes was troubled by the question of whether the provisions of the Act regulating the wages and hours of workers engaged in "production for commerce" lay within the scope of the commerce power. ${ }^{91}$ Hughes also was concerned that the statute provided notice insufficient to support criminal penalties, ${ }^{92}$ and it has been suggested that it was this concern rather than those over the Commerce Clause issue that were largely responsible for his hesitation in conference. ${ }^{93}$ This contention finds some support in the note that Hughes wrote on his return of Stone's draft opinion in a civil companion case to Darby, Opp Cotton Mills, Inc. v. Administrator of the Wage and Hour Division of the Department of Labor. ${ }^{94}$ Opp raised the same commerce power questions presented in Darby, but Stone used the Darby opinion to dispose of them, and therefore confined the Opp opinion to treatment of the issues peculiar to that litigation. ${ }^{95}$ But because Opp was a civil proceeding rather than a criminal prosecution, it did not present the notice issue that troubled Hughes in Darby. Thus, on his return of Stone's Darby opinion Hughes merely acquiesced, writing a grudging, "I will go along with this." 96 On his return of Stone's Opp opinion, by contrast, Hughes wrote, "Very careful and satisfactory." ${ }^{\prime 7}$ From this one might infer

90 Stone OT 1940 Docket Book; Roberts OT 1940 Docket Book; Douglas OT 1940 Docket Book. Reed OT 1940 Docket Book and Murphy OT 1940 Docket Book contain no record of the conference vote. McReynolds retired on February 1, 1941, two days before the Darby decision was announced.

91 Conference Notes, No. 82, United States v. F.W. Darby Lumber Co., Dec. 21, 1940, Box 51, William O. Douglas MSS, Manuscript Division, Library of Congress; Conference Notes, No. 82, United States v. F.W. Darby Lumber Co., Reel 123, Frank Murphy MSS, University of Michigan.

92 Id.; Charles Evans Hughes to Harlan Fiske Stone, Jan. 27, 1941, Box 66, Harlan Fiske Stone MSS, Manuscript Division, Library of Congress.

${ }_{93}$ See Richard D. Friedman, The Sometimes-Bumpy Stream of Commerce Clause Doctrine, 55 Ark. L. Rev. 981, 999-1000 (2003).

94312 U.S. 126 (1941).

95312 U.S. at 134.

${ }^{96}$ Opinion draft dated February 3, 1941, Box 66, Harlan Fiske Stone MSS, Manuscript Division, Library of Congress.

97 See Richard D. Friedman, Switching Time and Other Thought Experiments: The Hughes Court and Constitutional Transformation, 142 U. Pa. L. Rev. 1891, 1967 n.387 (1994). 
that the notice issue drove Hughes to the brink of dissent in Darby, but where he was untroubled by such a concern in $O p p$, he found no difficulty joining the majority. Yet the records of the $O p p$ conference pose difficulties for such an inference, for they record Hughes as passing at the Opp conference vote as well. ${ }^{98}$ It would appear that Hughes found "very careful and satisfactory" Stone's treatment of the issues with which he specifically dealt in the Opp opinion, but that he remained troubled by Stone's resolution in his Darby opinion of the commerce power issue common to both cases.99

98 Stone OT 1940 Docket Book; Roberts OT 1940 Docket Book; Douglas OT 1940 Docket Book. Reed OT 1940 Docket Book and Murphy OT 1940 Docket Book contain no record of the conference vote.

${ }^{99}$ Concerning the National Labor Relations Act, three unanimous victories for the NLRB also masked divisions at conference. In NLRB v. Mackay Radio \& Telegraph Co., 304 U.S. 333 (1938) (supporting NLRB ruling ordering interstate communication company to cease commission of unfair labor practices), the vote in conference was 5-1, with Butler dissenting and McReynolds passing. Cardozo and Reed took no part. Stone OT 1937 Docket Book; Butler OT 1937 Docket Book; Roberts OT 1937 Docket Book; Reed OT 1937 Docket Book. Brandeis OT 1937 Docket Book contains no record of the conference vote. Butler records Hughes as stating, "Different from earlier cases. Requires close analysis. Strikes - no unfair practice. Employer not bound to take them back. Findings show effort to reach agreement. Strike was in support demand for better wages. [Section] $10 \mathrm{c}$ cease \& desist from unfair labor practice. Here [section] 83 relied on. Company announced would take all but 11 . Very important - knife edge - not bound to take any strikers. Sole point is that employer did not have the right to leave out labor leaders. If there must be discrimination must be against followers as pl case contends." On his return of Stone's opinion McReynolds wrote, "I go along." Justice McReynolds, Return of NLRB v. Mackay Radio \& Telegraph Co., Box 64, Harlan Fiske Stone MSS, Manuscript Division, Library of Congress. The conference vote was again 5-1 in Ford Motor Co. v. NLRB, 305 U.S. 364 (1939) (supporting NLRB ruling ordering company to cease unfair labor practices), with Butler again dissenting, McReynolds again passing, and Roberts, who did not participate in the decision, absent. Stone OT 1938 Docket Book; Butler OT 1938 Docket Book; Roberts OT 1938 Docket Book. Brandeis OT 1938 Docket Book records the vote as 5-2, with McReynolds joining Butler in dissent. Reed OT 1938 Docket Book contains no record of the conference vote. And at the conference on NLRB v. Waterman Steamship Co., 309 U.S. 206 (1940) (holding that the NLRB's findings were sufficient to support its ruling ordering company to cease unfair labor practices), the vote was 6-2 to reverse, with McReynolds and Roberts voting to affirm, and Hughes voting to reverse "in part." Murphy took no part in the decision. Stone OT 1939 Docket Book; Reed OT 1939 Docket Book; Douglas OT 1939 Docket Book, Douglas Conference Notes on No. 193, NLRB v. Waterman Steamship Co., Box 39, William O. Douglas MSS, Manuscript Division, Library of Congress. On his return of Black's opinion McReynolds wrote, "I disagree. A mere question of fact that should be permitted to rest with the [lower court]. But I do not wish to say anything on the subject." Justice McReynolds, Return of NLRB v. 
The appearance of consensus also was created after conference in a number of decisions involving civil rights and civil liberties. Cantwell v. Connecticut ${ }^{100}$ unanimously incorporated the Free Exercise Clause of the First Amendment against the states and reversed the convictions of Jehovah's Witnesses for soliciting contributions without a license in violation of a state statute, and for common law breach of the peace. Stone and Douglas record the vote as unanimous at conference, with Hughes passing. ${ }^{101}$ Stone wrote "Fifth" next to his own vote and that of Reed. By this he apparently meant the fifth count of the indictment, which was for common law breach of the peace, as opposed to the third count, which was for violation of the statute. ${ }^{102}$ Douglas records Stone and Reed as voting to "reverse on $5^{\text {th }}$ count and affirm on $3^{\text {rd }}$."103

Another civil rights case that became a landmark in the field of federal courts was Railroad Commission of Texas v. Pullman. ${ }^{104}$ There the justices unanimously reversed the decree of a federal district court that had enjoined enforcement of a racially discriminatory staffing order of the state railroad commission. The Texas Supreme Court had not yet ruled on the question of whether the order actually was authorized by the relevant state statute, however, and Frankfurter's opinion held that a federal court petitioned for injunctive relief should abstain from creating "needless friction with state policies that may result from tentative constructions of state statutes and premature adjudication on their constitutionality." 105 The vote in conference to "Vacate and remand,"106 by

Waterman Steamship Co., Box 260, Hugo Black MSS, Manuscript Division, Library of Congress. Hughes wrote on his return, "You have dealt with this case very thoroughly and I acquiesce." Chief Justice Hughes, Return of NLRB v. Waterman Steamship Co., Box 260, Hugo Black MSS, Manuscript Division, Library of Congress.

100310 U.S. 296 (1940).

101 Stone OT 1939 Docket Book; Douglas OT 1939 Docket Book, Douglas Conference Notes on No. 632, Cantwell v. Connecticut, Box 39, William O. Douglas MSS, Manuscript Division, Library of Congress. Reed OT 1939 Docket Book contains no record of the conference vote. Hughes's opening remarks to the conference argued in favor of affirmance. McReynolds followed stating, "I would reverse." Del Dickson, The Supreme Court in Conference, 1940-1985, p. 392 (2001).

102 Stone OT 1939 Docket Book.

103 Douglas OT 1939 Docket Book.

104312 U.S. 496 (1941).

105 Id. at 497.

106 Stone OT 1940 Docket Book. 
contrast, was not unanimous. Each of the docket books records Roberts as passing, ${ }^{107}$ and Roberts noted that Black agreed to the disposition "with reservations." 108 Stone and Roberts place Hughes in the majority, ${ }^{109}$ but Douglas records the Chief as passing also, ${ }^{110}$ and Murphy reports that Hughes remarked that he would "wait to see [the] opinion."111 In the end, Hughes wrote on his return of Frankfurter's opinion, "I acquiesce." 112

In Pierre v. Louisiana, ${ }^{113}$ the justices unanimously voided an indictment of a black man for the murder of a white man issued by a grand jury from which blacks had been systematically excluded. At the February 11, 1939 conference, however, McReynolds and Butler had dissented. ${ }^{114}$ The grand jury and the original petit jury in the case had been selected from the same discriminatory general venire. Subsequently, however, the trial judge sustained the defendant's motion to quash the petit jury, but not to quash the indictment. A new petit jury consisting of both whites and blacks was selected, and that jury convicted the defendant. The Court held that it had been error not to quash the indictment. Butler has some notes on the case, which appear to express his own views concerning the vote on certiorari the preceding October. Butler apparently concluded that there had been no discrimination in the selection of the petit jurors by which the defendant had been tried, and that this was sufficient to satisfy constitutional requirements. On October 12 he wrote, "no qu as to petit jury. No proof of systematic exclusion of blacks." Also appearing in his notes is the following: "Negro convicted of murder alleged systematic exclusion of negroes. Held petit juror [sic] bad. But that this rule did not apply

107 Stone OT 1940 Docket Book; Roberts OT 1940 Docket Book; Douglas OT 1940 Docket Book; Murphy OT 1940 Docket Book. Reed OT 1940 Docket Book contains no record of the conference vote.

108 Roberts OT 1940 Docket Book.

109 Stone OT 1940 Docket Book; Roberts OT 1940 Docket Book.

110 Douglas OT 1940 Docket Book.

111 Murphy OT 1940 Docket Book.

112 Felix Frankfurter Papers (Harvard Law School), Part I, reel 2, quoted in Edward A. Purcell, Jr., Paradoxes of Court-Centered Legal History: Some Values of Historical Understanding for a Practical Legal Education, 64 J. Leg. Educ. 229, 240 n.44 (2014).

113306 U.S. 354 (1939).

114 Stone OT 1938 Docket Book; Butler OT 1938 Docket Book; Roberts OT 1938 Docket Book; Brandeis OT 1938 Docket Book; Reed OT 1938 Docket Book. 
to Grand Jury - Then on trial negroes called. Seems enough."115 In the end, however, he and McReynolds joined the majority to make a unanimous Court.

Records of conference votes in other unanimous decisions involving criminal law and criminal procedure similarly reveal that the initial instincts of McReynolds in such cases were not always reflected in the final votes. In Weiss v. United States, ${ }^{116}$ for example, the Court unanimously reversed convictions for conspiracy to commit mail fraud that were obtained on the basis of evidence acquired through illegal wiretaps. At the conference, however, McReynolds had passed. ${ }^{117}$ Similarly, the Court in Smith v. Texas ${ }^{118}$ unanimously reversed the rape conviction of a black man indicted by an all-white grand jury, but McReynolds had passed at the conference vote. ${ }^{119}$ In Lovell v. City of Griffin, ${ }^{120}$ the Court unanimously reversed the conviction of a Jehovah's Witness for distribution of pamphlet literature without a license. At the conference, however, McReynolds passed and Butler voted to dismiss the appeal. ${ }^{121}$ Butler records both McReynolds and Sutherland as also speaking in favor of dismissal, and in fact records a vote of 6-2 in favor of such a disposition, with only Black and Reed in dissent. But there was also a six-vote majority to reverse the conviction, and that was the course that the justices ultimately chose. Butler records Hughes as stating that the ordinance was "invalid," Brandeis characterizing it as "bad," and Butler saying that it was "bad on its face" but that the state court "did[n't] pass on [the] fed[eral] question." 122 In Lanzetta

115 Butler OT 1938 Docket Book.

116308 U.S. 321 (1939).

${ }_{117}$ Stone OT 1939 Docket Book; Reed OT 1939 Docket Book; Douglas OT 1939 Docket Book.

118311 U.S. 128 (1940).

${ }^{119}$ Stone OT 1940 Docket Book; Roberts OT 1940 Docket Book; Reed OT 1940 Docket Book; Douglas OT 1940 Docket Book. Murphy OT 1940 Docket Book contains no record of the conference vote. On his return of Black's circulated opinion, McReynolds wrote, "I shall acquiesce." Justice McReynolds, Return of Smith v. Texas, Box 264, Hugo Black MSS, Manuscript Division, Library of Congress.

120303 U.S. 444 (1938). Cardozo took no part in the decision.

121 Stone OT 1937 Docket Book; Butler OT 1937 Docket Book; Roberts OT 1937 Docket Book; Brandeis OT 1937 Docket Book. Reed OT 1937 Docket Book records McReynolds as voting to reverse.

122 Butler OT 1937 Docket Book. 
v. New Jersey ${ }^{123}$ the Court unanimously struck down a statute criminalizing gang membership on vagueness grounds. This time the conference vote was 4-3, with Hughes and Stone joining McReynolds in dissent. ${ }^{124}$ And in Chambers v. Florida, ${ }^{125}$ the justices unanimously reversed a state murder conviction obtained on the basis of a confession elicited under coercive circumstances. At the conference, however, Reed was paired with the dissenting McReynolds. ${ }^{126}$

123306 U.S. 451 (1939). Frankfurter took no part in the decision. In United States v. Falcone, 311 U.S. 205 (1940), the Court unanimously affirmed the Second Circuit's reversal of a conviction of the defendants for conspiracy to violate the revenue laws by selling goods to a person whom they knew was going to use those goods to make illegal alcohol. At the conference it seems that there were six votes to affirm, with McReynoids, Roberts, and Frankfurter voting to dismiss. Stone OT 1940 Docket Book; Roberts OT 1940 Docket Book; Reed OT 1940 Docket Book; Douglas OT 1940 Docket Book. Murphy records McReynolds and Roberts as voting to dismiss, and Frankfurter as "prefer[ring]" dismissal but voting to affirm. Murphy OT 1940 Docket Book. Subsequent correspondence between Stone and Frankfurter tends to corroborate Murphy's assessment of Frankfurter's flexibility, if not of his formal vote. See Frankfurter to Stone, Dec. 3, 1940; Stone to Frankfurter, Dec. 3, 1940; and Justice Frankfurter, Return of United States v. Falcone, Box 66, Harlan Fiske Stone MSS, Manuscript Division, Library of Congress. On his return of Stone's opinion, McReynolds wrote, "I voted to dismiss. I shall not object to yr. opinion. It seems tight." Justice McReynolds, Return of United States v. Falcone, Box 66, Harlan Fiske Stone MSS, Manuscript Division, Library of Congress.

${ }^{124}$ Stone OT 1938 Docket Book; Butler OT 1938 Docket Book; Roberts OT 1938 Docket Book; Reed OT 1938 Docket Book. Brandeis was absent from the conference, and his docket book contains no record of the conference vote. Brandeis OT 1938 Docket Book. Butler records the following statement, probably made by Hughes: "Sufficiency of evidence not involved. Sufficiency of statute - what is a 'gang' - what 'criminal purposes'."

125309 U.S. 227 (1940). Murphy took no part.

${ }^{126}$ Stone OT 1939 Docket Book; Douglas OT 1939 Docket Book; Douglas Conference Notes on No. 195, Chambers v. Florida, Box 39, William O. Douglas MSS, Manuscript Division, Library of Congress. Reed OT 1939 Docket Book contains no record of the conference vote. Following the decision in Chambers, the Court handed down a number of per curiam decisions reversing convictions on its authority. See, e.g., Lomax v. Texas, 313 U.S. 544 (1941), which was unanimous at conference, Stone OT 1940 Docket Book; Roberts OT 1940 Docket Book; Murphy OT 1940 Docket Book; Reed OT 1940 Docket Book has no record of the conference vote, nor does Douglas OT 1940 Docket Book, which simply notes, "reversed - per cur."; Smith v. O'Grady, 312 U.S. 329 (1941), which was unanimous at conference, Stone OT 1940 Docket Book; Roberts OT 1940 Docket Book; Douglas OT 1940 Docket Book; Murphy OT 1940 Docket Book (Reed OT 1940 Docket Book has no record of the conference vote); Canty v. Alabama, 309 U.S. 629 (1940), which Douglas reports as "grant \& reversed on Chambers v. Florida 3/9/40", Douglas OT 1939 Docket 
Finally, Reed also dissented, this time alone, at the conference on Perkins v. Elg. ${ }^{127}$ Ultimately the Court unanimously rebuffed an attempt to deport as an illegal alien a woman born in the United States to Swedish parents who had removed her to Sweden and renounced their American citizenship during her minority, but only because Reed suppressed his doubts. ${ }^{128}$

\section{Non-Unanimous Decisions with No Vote Changes}

When one examines the major non-unanimous decisions of the late Hughes Court in which there were no changes between the conference vote and the final vote on the merits, one detects a striking feature. With the exceptions of the Court's 8-1 decision in Palko v. Connecticut ${ }^{129}$ holding that the prohibition against double jeopardy did not apply to the states, and the 7-1 decision in

Book, and Reed OT 1939 Docket Book records as "3/1: Granted and reversed per curiam" (the Stone and Murphy docket books have no record of the vote). Vernon v. Alabama, 313 U.S. 547 (1941) was also a per curiam opinion following Chambers that was unanimous in conference, Stone OT 1940 Docket Book; Roberts OT 1940 Docket Book; Douglas OT 1940 Docket Book, though Douglas notes that "Stone wanted [a] full opinion" in this case involving "an Alabama defendant who confessed to murder after several late-night interrogations in secluded woods." Ross at 198. Reed OT 1940 Docket Book contains no record of the conference vote. It is noteworthy that McReynolds was no longer on the Court that decided Lomax, Smith, and Vernon.

127307 U.S. 325 (1939). Douglas took no part in the decision.

128 Stone OT 1938 Docket Book; Butler OT 1938 Docket Book; Roberts OT 1938 Docket Book; Brandeis OT 1938 Docket Book; Reed OT 1938 Docket Book. There was apparently some discussion of whether the decree should be modified to include the Secretary of State in its declaratory provision. Brandeis has the notation "Secy St." next to every member of the majority except for McReynolds and Hughes. Next to McReynolds he wrote "Excl. Secy., and next to Hughes he wrote "Incl. Secy." Stone wrote "Sec. of State" next to everyone except Reed and McReynolds. Roberts wrote " $S$ " next to everyone except Reed and McReynolds, and "no" next to McReynolds. Butler does not record a vote for Hughes, and has a notation next to McReynolds reading "Excluding Secy of State."

129302 U.S. 277 (1937). Butler dissented without opinion. Stone OT 1937 Docket Book; Butler OT 1937 Docket Book; Roberts OT Docket Book. Brandeis OT 1937 Docket Book. Butler records Hughes as saying, "What criterion to determine whether double jeopardy is within DP of $14-2$ phases - ask ourselves - what is fundamental to justice," and expressing the Chief's view that the judgment should be affirmed. There is extensive doodling on Roberts's page for Palko, giving the impression that he may have found the conference discussion tedious. 
Schneider v. State ${ }^{130}$ invalidating municipal ordinances prohibiting distribution of handbills on public streets, all of them concern issues of political economy. ${ }^{131}$ With respect to much of this portion of the Court's docket, the justices knew their minds, had strong views, and were disinclined to accommodate colleagues with whom they disagreed.

This pattern can be observed in several of the late Hughes Court's labor decisions. In Santa Cruz Fruit Packing Co. v. NLRB, ${ }^{132}$ where the Court upheld application of the National Labor Relations Act (NLRA) to striking warehousemen at a fruit packing plant, McReynolds and Butler were the sole dissenters both at conference and from the published decision. ${ }^{133}$ Later that year the Court decided Consolidated Edison Co. v. NLRB, ${ }^{134}$ which upheld application of the NLRA to an electrical power company. Though there were again no vote changes between the conference and the final decision, the dynamics within the conference were more complex. The conference vote was 6-2 to affirm the Circuit Court's judgment upholding the Board's order, with McReynolds and Butler

130308 U.S. 147 (1939). McReynolds dissented without opinion. Stone OT 1939 Docket Book; Reed OT 1939 Docket Book; Douglas OT 1939 Docket Book.

${ }_{131}$ Another arguable exception is Hague v. Committee for Industrial Organization, 307 U.S. 496 (1939), where the Court held that the Fourteenth Amendment secured the freedom of labor organizers to assemble peacefully to discuss labor issues. The vote in conference was 5-1 to affirm, with Butler voting to reverse, McReynolds voting to dismiss, and Frankfurter and Douglas not participating. Stone OT 1938 Docket Book; Butler OT 1938 Docket Book; Reed OT 1938 Docket Book; Roberts OT 1938 Docket Book. Roberts records that the case was initially brought up on March 4, after Brandeis had retired, and passed over. The case was again brought before the conference on April 15, two days before Douglas assumed his office. Roberts records the disposition that day as "Modify \& affirm," with the vote just as Stone and Butler recorded it. Though there were no vote changes between the conference and the published opinion, the five justices in the conference majority splintered into three different opinions. 307 U.S. at 500-32.

132303 U.S. 453 (1938). Cardozo and Reed took no part.

133 Stone OT 1937 Docket Book; Butler OT 1937 Docket Book; Roberts OT 1937 Docket Book; Brandeis OT 1937 Docket Book. Butler records Hughes as stating, "Finding not contested. Contest is made as application of the Act. $391 / 2$ i.c. [meaning $391 / 2 \%$ of the company's product was shipped in interstate commerce]." Butler then inserted in brackets "[Does effect of the unfair labor practice affect interstate commerce.]" Hughes continued, "See two Coronado Cases. Not \% in each case. Must be substantial. Cited close distinction in FELA cases." Reed OT 1937 Docket Book simply records, "Disqualified."

134305 U.S. 197 (1938). 
dissenting. ${ }^{135}$ There was a division among the majority, however, concerning whether the Board was without authority to issue the portion of its order contained in paragraph "f." Black and Reed maintained that the Board had such authority, whereas Hughes, Brandeis, Stone, and Roberts maintained that it did not. ${ }^{136}$ The Court ultimately affirmed and modified the judgment, holding that the paragraph " $f$ " of the Board's order was invalid. Butler and McReynolds agreed that paragraph " $f$ " was invalid, but dissented from the Court's holding that the Board had jurisdiction over the company. ${ }^{137}$ And Reed and Black concurred in all of the Court's opinion other than the portion modifying the order. ${ }^{138}$ Butler's notes record Hughes as stating at the conference, ' $\mathrm{f} f$ ' goes too far. ' $\mathrm{g}$ ' [another portion of the Board's order that the Court upheld] explain. Modify \& [af]firm." Brandeis, Stone, and Roberts expressed agreement with Hughes. Black expressed his preference for affirmance in toto, and Reed signaled his agreement with Black. Butler, of course, indicated that he favored reversal. Most interesting, however, is Butler's unusual account of the participation of McReynolds. When it came his turn to speak, the curmudgeonly Justice apparently reported that he had "nothing to say." 139

135 Stone OT 1938 Docket Book; Butler OT 1938 Docket Book; Roberts OT 1938 Docket Book; Brandeis OT 1938 Docket Book.

136 Roberts OT 1938 Docket Book records "modify" next to the "affirm" votes of Hughes, Brandeis, Stone, and himself. Stone records "and modify" next to the "affirm" votes of Hughes, Brandeis, and Roberts. Butler OT 1938 Docket Book records "mod. \& af." next to the votes of Hughes, Brandeis, Stone, and Roberts. Butler wrote "Af. i.e. uphold the Bd's order (f) striking down the contracts" next to the votes of Black and Reed. Reed OT 1938 Docket Book records Black and Reed as voting to "Affirm absolutely," and Hughes, Brandeis, Stone, and Roberts as voting to affirm "with reservations of modification."

137305 U.S. at 239-44.

138305 U.S. at $244-50$.

139 Butler OT 1938 Docket Book. Three other labor decisions of the 1938 Term merit brief mention. NLRB v. Fansteel Metallurgical Corp., 306 U.S. 240 (1939), held that participation by employees in a sit-down strike was good cause for discharge. Both the conference vote and the final vote on the merits were 5-2, with Stone concurring in part, Black and Reed dissenting in part, and Frankfurter not participating. Stone OT 1938 Docket Book; Roberts OT 1938 Docket Book. Butler OT 1938 Docket Book records the same vote, but places a question mark next to Stone's vote to affirm. Reed OT 1938 Docket Book recorded the vote as 4-2, with a question mark rather than a vote in Stone's column. Both NLRB v. Sands Mfg. Co., 306 U.S. 332 (1939) and NLRB v. Columbian Enameling \& Stamping Co., 306 U.S. 292 (1939) 
In New Negro Alliance v. Sanitary Grocery Co., ${ }^{140}$ the Court held that the Norris-LaGuardia Act deprived the federal District Court of jurisdiction to issue an injunction in a case in which an AfricanAmerican association picketed a grocer that did not employ any black clerks. Here again, McReynolds and Butler were the lone dissenters both at conference and from the published decision. ${ }^{141}$ Butler's notes indicate that the issue that divided the Court, both at conference and in the published opinions, was whether the dispute was a "labor dispute" within the meaning of the Act. ${ }^{142}$ New Negro Alliance was anticipated by Lauf v. E.G. Shinner \& Co., ${ }^{143}$ where the Court held that the federal District Court had exceeded its jurisdiction in issuing an injunction against a union picketing an employer because of its refusal to recognize the union as the exclusive bargaining agent for its employees. The vote in conference was 5-3, with McReynolds, Sutherland, and Butler dissenting. Sutherland retired before the decision was handed down, but McReynolds and Butler adhered to the positions that they had taken in conference. ${ }^{144}$ Here again Butler's notes indicate that the issue that divided the justices in conference as well as in the published opinions

affirmed decisions that Labor Board findings that employers had engaged in unfair labor practices were not supported by the evidence. The vote in each case was 5-2, with Black and Reed dissenting and Frankfurter taking no part. Butler records the vote in Columbian Enameling as identical with the final vote, but Stone and Roberts record Reed as passing, and Reed placed a question mark in his own column. Roberts records the conference vote in Sands as identical with the final vote, as does Stone, though Stone placed a question mark next to his own vote to affirm. Butler recorded Reed as passing, while Reed records himself as dissenting but places a question mark rather than a vote in Stone's column. Brandeis had retired, and so did not vote in any of these three cases. Douglas had not yet replaced him. Stone OT 1938 Docket Book; Butler OT 1938 Docket Book; Roberts OT 1938 Docket Book; Reed OT 1938 Docket Book.

140303 U.S. 552 (1938). Cardozo took no part.

141 Stone OT 1937 Docket Book; Butler OT 1937 Docket Book; Roberts OT 1937 Docket Book; Brandeis OT 1937 Docket Book. Reed OT 1937 Docket Book records only Reed's own vote to reverse.

142 Butler OT 1937 Docket Book. Brandeis recorded "labor dispute" next to the votes of every member of the majority except Reed, who appears to have preferred to place the decision on some other ground. Brandeis OT 1937 Docket Book.

143303 U.S. 323 (1938).

144 Stone OT 1937 Docket Book; Butler OT 1937 Docket Book. Roberts OT 1937 Docket Book; Brandeis OT 1937 Docket Book makes it impossible to see Black's vote because of a paste-over, but otherwise it is in accord with the records of the other justices. 
was whether the conflict was a "labor dispute" within the meaning of the Norris-LaGuardia Act. ${ }^{145}$ Finally, in Apex Hosiery v. Leader, ${ }^{146}$ Hughes, McReynolds, and Roberts dissented both at conference and in the published report from the Court's holding that the Sherman Act did not apply to laborers engaged in a sit-down strike. ${ }^{147}$

Such stability between the conference vote and the final vote on the merits also can be seen in some of the Court's later decisions concerning agricultural regulation. In Currin v. Wallace, ${ }^{148}$ where the Court upheld provisions of the Tobacco Inspection Act of 1935 regulating both interstate and intrastate sales, McReynolds and Butler registered the only dissents both at conference and from the published decision. ${ }^{149}$ Similarly, in Mulford v. Smith, ${ }^{150}$ where the Court upheld the Agricultural Adjustment Act of 1938, Butler records himself and McReynolds as isolated in dissent at conference. ${ }^{151}$ And in H.P. Hood \& Sons v. United States, ${ }^{152}$ which upheld orders issued pursuant to the Agricultural Marketing Agreement Act, Roberts joined

145 Butler OT 1937 Docket Book.

146310 U.S. 469 (1940).

147 Stone OT 1939 Docket Book; Douglas OT 1939 Docket Book. Reed OT 1939 Docket Book contains no record of the conference vote.

148306 U.S. 1 (1939).

${ }^{149}$ Stone OT 1938 Docket Book; Butler OT 1938 Docket Book; Roberts OT 1938 Docket Book; Brandeis OT 1938 Docket Book; Reed OT 1938 Docket Book.

150307 U.S. 38 (1939).

151 Butler OT 1938 Docket Book. Reed OT 1938 Docket Book similarly records the conference vote as 5-2 to affirm, with McReynolds and Butler in dissent and Hughes and Brandeis not voting. Roberts OT 1938 Docket Book contains no record of the conference vote. Stone's record of the conference vote is unclear. There are some erasure marks where Frankfurter's name was inserted by hand in place of Cardozo's, which appear to erase votes to affirm by Reed and Frankfurter. Assuming that Butler is correct that these two justices voted in conference as they did in the published decision, the conference vote was at least 5-2 to affirm, with McReynolds and Butler dissenting. Butler records the vote as 6-2, but Stone records no vote for Hughes. Butler OT 1938 Docket Book; Stone OT 1938 Docket Book. Mulford was argued on March 8 and decided on April 17. 307 U.S. 38. Hughes was absent from the Court due to illness from March 4 to April 15, and therefore was not present for the March 11 Mulford conference. See Hughes Attends Court Conference, Wash. Post, April 16, 1939, p. 3 ("Chief Justice Hughes attended a conference of the Supreme Court justices yesterday. It was his first visit to the Court since he became ill with grippe March 4.")

152307 U.S. 588 (1939). 
McReynolds and Butler in dissent both at conference and in the published decision. ${ }^{153}$

A similar persistence in voting behavior is evidenced by a quartet of decisions sustaining other New Deal initiatives. In Electric Bond \& Share Co. v. SEC ${ }^{154}$ where the justices upheld provisions of Public Utility Holding Company Act of 1935 requiring such companies to register with the SEC, McReynolds cast the lone dissenting vote both at conference and from the published decision. ${ }^{155}$ In United States v. Bekins, ${ }^{156}$ which upheld the Municipal Bankruptcy Act by a vote of 6-2, McReynolds and Butler also were alone in dissent at the conference. ${ }^{157}$ McReynolds and Butler again were consistently alone in dissent in Tennessee Electric Power Co. $v$. Tennessee Valley Authority, ${ }^{158}$ which turned back yet another challenge to the TVA. ${ }^{159}$ And in Sunshine Anthracite Coal Co.

153 Stone OT 1938 Docket Book; Butler OT 1938 Docket Book; Roberts OT Docket Book; Douglas OT 1938 Docket Book. Roberts, Stone, and Douglas record the conference vote as 6-3, with Douglas in the majority. Butler records the vote as 5-3, with the retired Brandeis not voting, and with no voting column for Douglas, who had joined the Court three weeks before the May 8, 1939 vote. Douglas notes that Roberts voted with the minority "on ground of delegation." Reed OT 1938 Docket Book contains no record of the conference vote.

154303 U.S. 419 (1938). Cardozo and Reed took no part in the decision.

155 Stone OT 1937 Docket Book; Butler OT 1937 Docket Book; Roberts OT 1937 Docket Book; Brandeis OT 1937 Docket Book; Reed OT 1937 Docket Book. Stone, Butler, Roberts, and Reed all record the vote as 6-1, with the ailing Cardozo absent and Reed not participating. Brandeis does not record a vote for Hughes, but records Hughes as stating, "Qu - are prs [petitioners] subject to congressional regulation. EB\&S and others under it \& Ebasco have extensive use of mails. See prs brief p. 11 prs reply brief concession yes directly engaged in i.c. (at least EB\&S, Ebasco, Am. Gas \& three others).... Denials in decree are penalties for failure to give its information - not so arbitrary as to deny due process."

156304 U.S. 27 (1938). Cardozo took no part in the decision.

157 Stone OT 1937 Docket Book; Butler OT 1937 Docket Book; Roberts OT 1937 Docket Book; Reed OT 1937 Docket Book. Brandeis OT 1937 Docket Book contains no record of the conference vote.

158306 U.S. 118 (1939). Reed took no part in the decision.

159 Stone OT 1938 Docket Book; Brandeis OT 1938 Docket Book. Roberts also records Butler as voting with McReynolds to reverse, though his record contains a crossed-out vote to affirm in Butler's column, suggesting the possibility of a changed vote. Roberts OT 1938 Docket Book. Butler records the December 3 vote as 4-2 (rather than 5-2 as the others do), with Reed "out," Brandeis not voting, and Cardozo not yet replaced by Frankfurter. Reed OT 1938 Docket Book records McReynolds as not voting, Reed as "Disq.", and all others voting to affirm. Butler records Hughes as presenting the case and, after several remarks, concluding "Case is 
v. Adkins, ${ }^{160}$ McReynolds was the lone dissenter both at conference and from the final decision upholding the National Bituminous Coal Conservation Act of 1937. ${ }^{161}$ The New Dealers were dealt a blow, by contrast, when in Morgan // the Court held that a hearing conducted under the auspices of the Secretary of Agriculture had failed to satisfy "basic concepts of fair play." 162 This time it was Black who was alone in dissent both at conference and in the published decision. ${ }^{163}$

Finally, a quartet of decisions concerning state regulation and taxation likewise saw no changes between the conference vote and the final vote on the merits. Connecticut General Life Ins. Co. v. Johnson ${ }^{164}$ held that a California tax imposed on a Connecticut corporation for the privilege of doing business within the state violated the Due Process Clause. Black cast the lone dissenting vote both at conference and from the published opinion. ${ }^{165}$ Milk Control Board v. Eisenberg Farm Products ${ }^{166}$ upheld Pennsylvania's Milk Control Law against a dormant Commerce Clause challenge by a vote of 7-2, with McReynolds and Butler dissenting both at the conference and from the published opinion. ${ }^{167}$ In Madden v. Kentucky, ${ }^{168}$ the Court upheld a state tax against equal protection and privileges or immunities challenges and partially overruled Colgate

controlled by Ala Co. v. Ickes - Did pls have any right to be free from comp. Pls have no right like cert of con of necessity."

160310 U.S. 381 (1940).

151 Stone OT 1939 Docket Book; Douglas OT 1939 Docket Book. Reed OT 1939 Docket Book contains no record of the conference vote.

162 Morgan v. United States, 304 U.S. 1, 22 (1938). Cardozo and Reed took no part in the decision.

163 Stone OT 1937 Docket Book; Butler OT 1937 Docket Book; Roberts OT 1937 Docket Book; Brandeis OT 1937 Docket Book. Reed OT 1937 Docket Book contains no record of the conference vote.

164303 U.S. 77 (1938). Cardozo took no part in the decision.

165 Stone OT 1937 Docket Book; Roberts OT 1937 Docket Book; Brandeis OT 1937 Docket Book. Butler OT 1937 Docket Book contains no record of the conference vote.

165306 U.S. 346 (1939).

167 Stone OT 1938 Docket Book; Butler OT 1938 Docket Book; Brandeis OT 1938 Docket Book; Reed OT 1938 Docket Book. Roberts OT 1938 Docket Book also records the conference vote as 7-2, though there is a mark in Butler's "Reverse" column suggesting the possibility that he may initially have voted with the majority.

${ }^{168} 309$ U.S. 83 (1940). Hughes published a brief concurrence. 
v. Harvey. ${ }^{169}$ McReynolds and Roberts, remaining members of the dwindling Colgate majority, dissented alone both at the conference and from the published decision. ${ }^{170}$ And in Railroad Commission of Texas v. Rowan \& Nichols Oil Co. ${ }^{171}$ the Court held that an oil proration order of the Texas Railroad Commission did not deprive the company of its property without due process, and effectively overruled Thompson v. Consolidated Gas Utilities Corp. ${ }^{172}$ The vote both in the conference and in the published decision was 6-3, with the last remaining members of the Thompson majority - Hughes, McReynolds, and Roberts - in dissent. ${ }^{173}$

\section{Non-Unanimous Decisions With Vote Changes}

Alongside these instances of voting stability one finds numerous cases in which the justices of the late Hughes Court altered their votes between the conference and the final decision. Among these cases are some of the period's major constitutional landmarks. For example, Erie Railroad v. Tompkins ${ }^{174}$ overruled Swift v. Tyson ${ }^{175}$ and held that federal courts sitting in diversity were required to apply the decisional law of state courts. The conference vote was 5-2 to reverse, with Black and Reed voting to affirm the judgment of the lower court. The ailing Cardozo was absent, McReynolds passed, and Butler voted with the majority in favor of reversal. ${ }^{176}$

169296 U.S. 404 (1935) (invalidating a state tax by a vote of 6-3 on the ground that it violated the Privileges or Immunities Clause of the Fourteenth Amendment).

170 Stone OT 1939 Docket Book; Reed OT 1939 Docket Book; Douglas OT 1939 Docket Book.

171310 U.S. 573 (1940).

172300 U.S. 55 (1937) (unanimously invalidating oil proration order of Texas Railroad Commission on the ground that it deprived the company of property without due process).

173 Stone OT 1939 Docket Book; Douglas OT 1939 Docket Book. Reed OT 1939 Docket Book contains no record of the conference vote.

174304 U.S. 64 (1938). Cardozo took no part in the decision.

17541 U.S. 1 (1842).

176 Stone OT 1937 Docket Book; Butler OT 1937 Docket Book; Roberts OT 1937 Docket Book; Brandeis OT 1937 Docket Book. Reed OT 1937 Docket Book records the vote as $6-2$, with McReynolds in the majority. Butler records Hughes as stating in his presentation, "Very thin on con[tributory] neg[ligence] but very good judge." Next Hughes "explained Penn case alleged [permissive or persuasive] - not recognized in this state - if that is local law - then no case - B \& O v. Baugh - fellow servant case - Buetler Case followed Baugh case - Breslin Case - Penn rule explicit. if 
Next to the votes of Black and Reed, Butler wrote, "Penn law but for pl." These two Roosevelt appointees apparently agreed that Swift should be overruled, but believed that the Railroad was liable to Mr. Tompkins under the applicable Pennsylvania decisional law. Neither of these justices expressed such views in the published decision. Black joined the majority opinion, and Reed wrote separately to express his concurrence in the result and the reasoning of that opinion except insofar as it maintained that the course previously pursued by federal courts had been unconstitutional. ${ }^{177}$ McReynolds ultimately joined Butler's opinion defending Swift and concluding that its constitutional validity "need not be considered, because under the law, as found by the courts of Pennsylvania and generally throughout the country, it is plain that the evidence required a finding that plaintiff was guilty of negligence that contributed to cause his injuries and that the judgment below should be reversed upon that ground." 178

In United States v. Carolene Products Co. ${ }^{179}$ the Court upheld the federal Filled Milk Act of 1923 , which prohibited the interstate transportation of the substance for which it was named. In the final decision, only McReynolds dissented. Black concurred in the result and all of the opinion except for the Part labeled "Third" - the portion containing the famous Footnote Four. Butler wrote a separate opinion concurring in the result. At the conference, however, Butler

in statute would be followed in fed[eral] case." The reference to "B \& O v. Baugh" is to Baltimore \& O. R. Co. v. Baugh, 149 U.S. 368 (1893), in which the Court held that general rather than local law governed a suit brought in diversity against the railroad by an employee injured by the negligence of his fellow servant. The reference to "Buetler Case" is to Buetler v. Grand Trunk Junction Ry. Co., 224 U.S. 85 (1912), a brief Holmes opinion in which the Court unanimously followed Baugh and applied the general law fellow-servant rule to a tort suit brought in diversity. The reference to "Breslin Case" is to the recent First Circuit decision in Boston \& Maine Rd. v. Breslin, 80 F.2d 749 (1 ${ }^{\text {st }}$. Cir. 1935), cert. den. 297 U.S. 715, which was relied upon by the Railroad in its brief. Brief on Behalf of Petitioner Erie Railroad Co., Erie Railroad Co. v. Tompkins, at 43 . There the court applied the judge-made law of the lex loci to a tort suit brought under federal diversity jurisdiction.

177304 U.S. at $90-91$.

178304 U.S. at 80-90. On a separate page pasted into Butler's entry for Erie appears "p. 7 [presumably of Brandeis's circulated draft]. If only a question of statutory construction was involved, we should not be prepared to abandon etc." Butler OT 1937 Docket Book.

179304 U.S. 144 (1938). Cardozo and Reed did not participate in the decision. 
recorded himself as passing, ${ }^{180}$ and the account of Roberts corroborates Butler's record. ${ }^{181}$ Stone apparently understood things differently, and listed Butler as in dissent. ${ }^{182}$ Whatever the case, Butler ultimately acquiesced in the judgment of the majority. In United States v. Rock Royal Co-Operative, Inc., ${ }^{183}$ another of the period's many dairy-related decisions, it was Stone who was on the move. There a divided Court upheld the constitutionality of the Agricultural Marketing Agreement Act and a minimum milk price order issued pursuant to its authority. Stone and Frankfurter joined Reed's opinion for the Court, with Black and Douglas concurring specially, and Hughes, McReynolds, Butler, and Roberts dissenting. At conference, however, the vote had been evenly divided, with Stone passing. ${ }^{184}$

There was also a great deal of fluidity in the rapidly-developing domain of intergovernmental tax immunities. In Helvering v. Mountain Producers Corporation, ${ }^{185}$ the federal government had granted land to the state of Wyoming for the purpose of supporting common schools. The state in turn leased some of the land to the corporation for the purpose of extracting oil and gas. The state reserved a royalty, and the balance of the income from production at the site flowed to the company. The majority held that the corporation was not an instrumentality of the state so as to render its

180 Butler OT 1937 Docket Book. Butler records Hughes as citing "238/446 Boric Acid," a reference to Price v. Illinois, 238 U.S. 446 (1915), which upheld a prohibition on the sale of food preservatives containing boric acid. That case, Hughes indicated, stood for the proposition that such a statute was "good unless palpably without foundation." Here, Hughes argued, "On face of stat[ute] can't be said it is invalid," adding that "If [the statute had] no basis in reason [that] is [a] defense" to prosecution. Hughes also raised the issue of "deception" in the marketing of filled milk, and cited the precedent of Purity Extract \& Tonic Co. v. Lynch, 226 U.S. 192 (1912) (upholding state liquor regulation).

181 Roberts OT 1937 Docket Book. Reed OT 1937 Docket Book lists the vote as 5-0 to reverse, with Butler not voting, Reed "disqualified," and Cardozo absent. Reed recorded no vote for McReynolds.

182 Stone OT 1937 Docket Book.

183307 U.S. 533 (1939).

184 Stone OT 1938 Docket Book; Butler OT 1938 Docket Book; Roberts OT 1938 Docket Book (showing a dot rather than a check mark in Stone's "affirm" column); Douglas OT 1938 Docket Book. Reed OT 1938 Docket Book contains no record of the conference vote.

185303 U.S. 376 (1938). 
income constitutionally immune from federal taxation, and expressly overruled two contrary precedents. ${ }^{186}$ The final vote was 5-2, with McReynolds and Butler dissenting, and Cardozo and Reed not participating. At the conference, there had been five votes for the ultimate disposition, but the other four justices did not vote. Both Butler and Cardozo were absent; former Solicitor General Reed sat the vote out; and McReynolds passed. ${ }^{187}$

In Helvering $v$. Gerhardt, ${ }^{188}$ the Court held that the salaries of a construction engineer and two assistant general managers employed by the New York Port Authority were subject to federal income taxation. The vote in the decision was 5-2, with McReynolds and Butler dissenting, and Cardozo and Reed taking no part. At the conference, however, the vote had been 4-2. Both Stone and Roberts record Hughes as not voting; 189 Butler records Hughes in the majority, but he records no vote for Black. ${ }^{190}$ It appears that the records of Stone and Roberts are more likely correct. First, Black indicated in his published concurrence that he was prepared to re-examine the Court's entire line of intergovernmental tax immunity jurisprudence from top to bottom. ${ }^{191}$ It seems unlikely that his vote in Gerhardt was ever in doubt. Second, the Gerhardt Court reversed the Second Circuit, but Butler records Hughes as concluding his presentation to the conference with the statement, "Affirm." 192 After Hughes spoke he heard several of his colleagues speak and vote in favor of reversal. It seems likely that the Chief Justice, who voted last, was in some doubt when the time came to cast his conference vote.

Part of the Gerhardt discussion concerned a case that the Court had decided the previous year, Brush v. Commissioner. ${ }^{193}$ There the

186 Burnet v. Coronado Oil \& Gas Co., 285 U.S. 393 (1932); Gillespie v. Oklahoma, 257 U.S. 501 (1922).

187 Stone OT 1937 Docket Book; Roberts OT 1937 Docket Book; Brandeis OT 1937 Docket Book. Butler OT 1937 Docket Book contains no record of the conference vote. Reed OT 1937 Docket Book simply records, "Not voting."

188304 U.S. 405 (1938).

189 Stone OT 1937 Docket Book; Roberts OT 1937 Docket Book.

190 Butler OT 1937 Docket Book. Brandeis OT 1937 Docket Book and Reed OT 1937 Docket Book contain no record of the conference vote.

191304 U.S. at 424-27.

192 Butler OT 1937 Docket Book. Butler records Hughes's presentation thusly: "Stated case. Is agency free fr[om] tax if yes then these men are - ? Affirm."

193300 U.S. 352 (1937). 
Court held that the salary of the Chief Engineer of New York City's Bureau of Water Supply was constitutionally immune from federal income taxation, and Hughes had joined the majority opinion. At the conference the vote had been 6-2 to reverse, with Brandeis and Roberts dissenting and Stone passing. ${ }^{194}$ Stone placed a question mark next to Cardozo's vote to reverse, ${ }^{195}$ and the two of them ultimately concurred in the result on the non-constitutional ground that Brush's salary was exempted under a Treasury regulation the validity of which had not been challenged by the Government. ${ }^{196}$ Roberts, joined by Brandeis, published a dissent in which he maintained that Brush's salary was subject to taxation under a proper understanding of the principles of intergovernmental immunity. ${ }^{197}$ At the Gerhardt conference Butler summarized Roberts's remarks this way: "Goes on his dissent in Brush case."198 In Gerhardt, Roberts joined Stone's opinion expressly limiting Brush to its nonconstitutional foundations. ${ }^{199}$

Gerhardt was followed in Graves v. New York ex rel. O'Keefe, 200 which held that the salary of an examining attorney employed by the Federal Home Owners' Loan Corporation was subject to nondiscriminatory taxation by the state of his residence. At the conference the vote was 5-2, with McReynolds and Butler dissenting. Brandeis had retired and Douglas had not yet been confirmed, and the ailing Hughes was absent. ${ }^{201}$ Ultimately the decision was 6-2,

194 Stone OT 1936 Docket Book; Butler OT 1936 Docket Book; Roberts OT 1936 Docket Book; Brandeis OT 1936 Docket Book contains no record of the conference vote.

195 Stone OT 1936 Docket Book.

196300 U.S. at 374 ("We concur in the result upon the ground that the petitioner has brought himself within the terms of the exemption prescribed by Treasury Regulation 74, Article 643, which, for the purposes of this case, may be accepted as valid, its validity not being challenged by counsel for the government. In the absence of such a challenge, no opinion is expressed as to the need for revision of the doctrine of implied immunities declared in earlier decisions. We leave that subject open.")

197300 U.S. at $374-78$.

198 Butler OT 1937 Docket Book.

199304 U.S. at $422-23$.

200306 U.S. 466 (1939).

201 Stone OT 1938 Docket Book; Roberts OT 1938 Docket Book; Reed OT 1938 Docket Book. None of these records a vote for Hughes. Butler OT 1938 Docket Book records Hughes as "ab," and does not record a vote for Reed. O'Keefe was argued 
with Hughes concurring in the result and Frankfurter writing a concurring opinion. The majority expressly overruled ${ }^{202}$ the venerable precedent of Collector v. Day ${ }^{203}$ and the very recent decision of New York ex rel. Rogers v. Graves. ${ }^{204}$

At the Gerhardt conference Roberts also stated that he was "Sorry he agreed with Evans Case," 205 referring to the 1920 decision in Evans v. Gore ${ }^{206}$ holding that a federal statute taxing the income of a federal district judge confirmed before its enactment worked an unconstitutional diminution of his compensation while in office in violation of Article III, Sec. 1 of the Constitution. In 1925, Miles v. Graham had extended Evans to prohibit taxation of the income of federal judges confirmed after enactment of the taxing statute. ${ }^{207}$ Evans would be limited, and Miles v. Graham overruled, in the 1939 case of O'Malley v. Woodrough. ${ }^{208}$ There the Court held that a provision of the Revenue Act of 1936 that re-enacted a provision of the Revenue Act of 1932 taxing the income of federal judges confirmed after June 6, 1932 was constitutional as applied to judges confirmed after that date.

At the $O^{\prime}$ Malley conference, in which McReynolds did not participate, only Butler voted to preserve Miles and invalidate the tax. ${ }^{209}$ Among the remaining justices the discussion centered on whether to overrule only Miles, or to include Evans on the chopping block as well. Here the reports diverge in their details. Stone records Roberts, Frankfurter, and Reed as favoring the former path, voting to

on March 6 and decided on March 27. 306 U.S. 466. Hughes was absent from the Court due to illness from March 4 to April 15, and therefore was not present for the

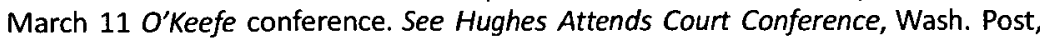
April 16, 1939, p. 3 ("Chief Justice Hughes attended a conference of the Supreme Court justices yesterday. It was his first visit to the Court since he became ill with grippe March 4.")

202306 U.S. at 486.

20311 Wall. 113 (1871).

204299 U.S. 401 (1937) (holding the salary of the general counsel of the Panama Railroad Company immune from state taxation).

205 Butler OT 1937 Docket Book.

206253 U.S. 245 (1920).

207268 U.S. 501 (1925).

${ }^{208} 307$ U.S. 277 (1939). McReynolds took no part in the decision.

${ }^{209}$ Stone OT 1938 Docket Book; Butler OT 1938 Docket Book; Roberts OT 1938 Docket Book; Douglas OT 1938 Docket Book. 
uphold the tax as applied to judges confirmed "since 1932." 210 Butler attributed this position to Hughes, Roberts, and Frankfurter, ${ }^{211}$ and Roberts ascribed this view to himself, Reed, and Douglas. ${ }^{212}$ Reed listed Hughes, Roberts, himself, and Frankfurter as voting to "overrule Graham" only, and Douglas recorded only Reed and Frankfurter as favoring this disposition. ${ }^{213}$ Both Butler and Stone record Black alone as voting to "overrule both" Miles and Evans, ${ }^{214}$ while Roberts adds to this list Frankfurter and Stone. ${ }^{215}$ Reed listed Black, Stone, and Douglas as voting to "Generally overrule Evans v. Gore," and Douglas's account accords with Reed's. ${ }^{216}$ Stone records himself and Hughes as stating that they would be content "either way," 217 while Douglas notes that "Hughes and Roberts would join in above if opinion were written broadly [i.e., overruling both Miles and Evans] but prefer narrower ground." 218 In Frankfurter's published opinion the Court expressly overruled only Miles, though it did include some language indicating disapproval of Evans, and no justice wrote separately to argue that Evans should be overruled.

In the field of labor relations, NLRB v. Fainblatt ${ }^{219}$ upheld application of the NLRA to a company processing materials into women's sports garments on a contract basis. Only McReynolds and Butler dissented from the published opinion. The reports of the conference votes differ, but each of them depicts a Court that was fluid between the conference vote and the final vote on the merits. Stone records himself, Roberts, Black, Reed, and Frankfurter in the

210 Stone OT 1938 Docket Book. Stone has an illegible notation next to Douglas's vote to reverse.

211 Butler OT 1938 Docket Book. Butler initially recorded Douglas as voting to overrule only Miles, but then crossed his vote out.

212 Roberts OT 1938 Docket Book.

213 Douglas OT 1938 Docket Book.

214 Stone OT 1938 Docket Book; Butler OT 1938 Docket Book.

215 Roberts OT 1938 Docket Book.

216 Douglas OT 1938 Docket Book ("Black, Douglas, \& Stone [would] Reverse \& overrule Evans v. Gore \& Miles v. Graham").

217 Stone OT 1938 Docket Book.

${ }^{218}$ Douglas OT 1938 Docket Book. Douglas records Hughes as stating the case, "(1) Retroactivity argument of no avail. (2) Either tax is a diminution or it is not. If not diminution no question. If it is, nevertheless it is a valid deduction from salary. In either event Woodrough must pay. Evans v. Gore not involved."

219306 U.S. 601 (1939). 
majority, McReynolds and Butler in dissent, and the ailing and absent Hughes as not voting. ${ }^{220}$ Roberts's record is similar, though he records himself as passing also. ${ }^{221}$ Reed's account corroborates that of Roberts. ${ }^{222}$ And Butler records himself as alone in dissent, with Roberts and McReynolds passing, and Hughes not voting. ${ }^{223}$ It appears that in March of 1939 Roberts may have been uncertain whether Fainblatt's operations lay within the scope of congressional power over interstate commerce. ${ }^{224}$

220 Stone OT 1938 Docket Book. Brandeis had retired, and Douglas had not yet been confirmed as his replacement.

221 Roberts OT 1938 Docket Book.

222 Reed OT 1938 Docket Book.

223 Butler OT 1938 Docket Book.

${ }^{224}$ Two other labor relations cases are worthy of brief mention. In United States v. Hutcheson, 312 U.S. 219 (1941), the Court held that a trade union's secondary boycott did not violate the Sherman Act. The case was decided by a vote of 5-2, with Hughes and Roberts dissenting. McReynolds retired two days before the decision was announced and took no part in it. Former Attorney General Murphy also took no part. Stone recorded the conference vote as 6-2, with Murphy in the majority. Stone OT 1940 Docket Book. Roberts recorded the vote as 5-2, adding the note, "Murphy takes no part." However, it appears that Murphy may initially have voted, as Roberts placed a check mark in Murphy's "affirm" column that was then crossed out. (Roberts's entry also contains a crossed-out vote to reverse for Black, who voted with the majority to affirm.) Roberts OT 1940 Docket Book. Douglas OT 1940 Docket Book records the vote as 5-2 with McReynolds passing and Murphy not participating. Murphy did not record the conference vote, though he did write "disqualified" next to his own name. Murphy OT 1940 Docket Book. Reed OT 1940 Docket Book contains no records of the conference vote.

It appears that Murphy may also have been uncertain about whether he should participate in Milk Wagon Drivers Union of Chicago, Local 753 v. Meadowmoor Dairies, Inc., 312 U.S. 287 (1941). There the Court upheld over First Amendment objections an injunction against union picketing that had been accompanied by violence. The vote was 5-3, with Justices Black, Douglas, and Reed dissenting, and the recently-retired McReynolds not yet replaced. Roberts recorded the vote as 6-3. at the December 21, 1940 conference, Roberts OT 1940 Docket Book, with both McReynolds and Murphy in the majority and Douglas, Reed, and Black in dissent. Stone, however, again provides a different account. He records Frankfurter, Roberts, and himself as voting to affirm; Black, Reed, and Douglas to reverse; Hughes both to affirm and reverse; and McReynolds not voting. Stone also has no recorded vote for Murphy, though there is an erased vote to affirm in Murphy's column. Stone OT 1940 Docket Book. Reed OT 1940 Docket Book and Douglas OT 1940 Docket Book record the vote as 5-3, with no recorded vote for Murphy. Justice Murphy himself records the vote as 5-3 with McReynolds voting in the majority. In his column appears the notation, "absent - your vote not needed." Murphy OT 1940 Docket Book. Irrespective of whether Murphy's vote was needed, the published report contains no indication that he did not participate. 
The 1939 decision of Coleman v. Miller ${ }^{225}$ concerned the status of the proposed Child Labor Amendment, which Congress had passed in 1924, but which had yet to be ratified by the requisite number of states. In January of 1925, the Kansas state legislature had adopted a resolution rejecting the proposed amendment. In January of 1937 , however, the state senate had divided evenly on a resolution to ratify the amendment, and the state's Lieutenant Governor had cast the deciding vote in favor of ratification. The lower house then adopted a resolution of ratification. Members of the legislature claiming that the Lieutenant Governor had no right to vote on the senate resolution brought an action in mandamus seeking to restrain various state officers from taking steps to certify that the legislature had ratified the amendment. The petition also contended that the proposed amendment was stale and no longer subject to ratification because it had not been ratified within a reasonable time. The state supreme court found that the Lieutenant Governor had been entitled to vote on the resolution, that the proposed amendment remained vital and subject to ratification, and that the legislature had ratified the amendment. That court therefore denied the writ of mandamus. ${ }^{226}$

The threshold question before the Supreme Court of the United States was whether the Court had jurisdiction of the controversy. More particularly, the issue was whether the members of the state legislature who had brought the action had standing to seek a writ of certiorari. In the published opinion the Court split on this issue 5-4, with Roberts, Black, and Douglas joining Frankfurter's opinion maintaining that the Court lacked jurisdiction because the petitioners lacked standing. ${ }^{227}$ The numerical vote had been the same at the April 22nd conference, but with a different line-up. There McReynolds had taken the view that there was no jurisdiction, and Roberts had voted to recognize jurisdiction. These two justices switched places between the conference and the final decision. ${ }^{228}$

\footnotetext{
225307 U.S. 433 (1939).

226307 U.S. at $435-37$.

227307 U.S. at 460-70 (separate opinion of Frankfurter, J.).

${ }^{228}$ Stone OT 1938 Docket Book; Butler OT 1938 Docket Book; Roberts OT 1938 Docket Book; Douglas OT 1938 Docket Book; Reed OT 1938 Docket Book.
} 
The second question was whether to affirm the judgment of the state court on the merits. Here the vote in the published decision was 7-2. Hughes's opinion for the Court held that the question of whether the ratification of the amendment was effective in view of its earlier rejection by the state legislature was a political question to be determined by Congress. ${ }^{229}$ Hughes further opined that the question of whether the amendment had lost its vitality through lapse of time was similarly non-justiciable. ${ }^{230}$ Roberts, Frankfurter, and Douglas joined Black's concurring opinion, which underscored their view that Congress alone held exclusive power over the political process of constitutional amendment, and that the courts had no business pronouncing upon that process. ${ }^{231}$ McReynolds joined Butler's dissent, which maintained that the proposed amendment was no longer subject to ratification because it had not been ratified within a reasonable time. Butler's opinion did not speak to the issue of the legislature's previous rejection of the proposed amendment. ${ }^{232}$ Here again, however, the ultimate vote was at variance with the conference tally. At the conference, McReynolds had not voted on the merits, passing because of his view that the Court did not have jurisdiction of the case. Stone and Roberts had been with Butler in dissent, though it appears from the question marks that Stone placed next to his and Roberts's votes that their votes to reverse had been tentative. ${ }^{233}$ Stone ultimately joined Hughes on the merits, and Roberts ultimately joined Black. The deserted Butler had to be consoled by McReynolds's election to join him in dissent.

There was a third merits issue in Coleman that was not disaggregated in the conference tallies but was given brief, separate treatment in Hughes's opinion. The petitioners claimed that the Lieutenant Governor was not a part of the "legislature" under the Kansas constitution as it had been construed by the state's highest court, and therefore was not eligible under Article $V$ of the federal

\footnotetext{
229307 U.S. at $447-51$.

230307 at $451-56$.

231307 U.S. at $456-60$ (Black, J., concurring).

232307 U.S. at 470-74 (Butler, J. dissenting).

233 Stone OT 1938 Docket Book; Butler OT Docket Book; Roberts OT 1938 Docket Book; Douglas OT 1938 Docket Book. Butler did not record a vote for Stone on the merits. Reed OT 1938 Docket Book records the merits vote as 6-2, with Butler and Roberts in dissent, and McReynolds not voting.
} 
Constitution to cast the deciding vote on ratification. Hughes reported that " $[w]$ hether this contention presents a justiciable controversy, or a question which is political in its nature and hence not justiciable, is a question upon which the Court is equally divided and therefore the Court expresses no opinion upon that point."234

Scholars understandably have been puzzled by how a decision in which all nine of the justices participated could have been "equally divided" on this issue. Shortly after the decision was handed down, the Vale Law Journal published an anonymous Note, which Bennett Boskey later attributed to Yale Law Professor Harry Shulman, ${ }^{235}$ entitled Sawing a Justice in Half. ${ }^{236}$ "Opinions of the Supreme Court delivered in the last weeks of this Term," the author wrote, "exhibit a capacity in that Court for division sufficient to confound prophets and critics of all schools - legalistic, metaphysical, psychological and economic. But the division in Coleman v. Miller, recorded June 5 th, should astonish even a Yogi magician." 237 After surveying the various possibilities, the author concluded that

\footnotetext{
"[o]nly Justices McReynolds and Butler could properly refuse to consider the question; for they voted for the petitioners on other grounds and therefore could have found it unnecessary to pass upon additional reasons supporting the same conclusion. Yet, failing to carry a majority on those grounds, they were under some duty to see whether they could find a majority for their result on any of the other grounds urged."238
}

The still-perplexed author was left with a series of questions: "What really did happen? Did a Justice refuse to vote on this issue? And if he did, was it because he could not make up his mind? Or is it possible to saw a Justice vertically in half during a conference and have him walk away whole?"239

234307 U.S. at $446-47$.

235 Recollections of West Virginia Board of Education v. Barnette, 81 St. John's L. Rev. 755, 787 (2007).

23648 Yale L.J. 1455 (1939).

237 Id. at 1455 (footnotes omitted).

238 Id. at 1458.

239 ld. 
In a conversation that took place more than half a century later, Boskey related that:

"I later found out through Felix Frankfurter what had really happened in that case. Justice McReynolds, who was a very ornery Justice, used to go off a little bit early before the end of the Term on vacation. And in this particular case, the point involved was a new point that came up after Justice McReynolds had gone off on vacation. And nobody was going to try and call him back-he would have told them, frankly, 'Go to hell.' He wouldn't have come back. So Hughes just said, 'On this issue, the Court is evenly divided."'240

It seems that McReynolds was indeed absent from the final meeting during which the justices met to deliberate on the case. Coleman was delivered on the final opinion day of the term, June 5, 1939. On May 30, Chief Justice Hughes wrote to his colleagues that "[f]our opinions have been circulated" in Coleman - Hughes's, Black's, Frankfurter's, and Butler's - "and, in view of the shortness of time, it seems to me desirable that we should have a conference as soon as possible in order to determine whether an opinion can be written for the Court and, if so, what it shall decide. Accordingly, I ask that the brethren meet in conference tomorrow, Wednesday, at noon." 241 We know that McReynolds was absent from the Court's final session on June $5,{ }^{242}$ and the docket books of his colleagues reveal that he also did not attend the Court's final conference on June $3 .^{243}$ On June 16 , McReynolds's clerk for that Term

${ }^{240} 81$ St. John's L. Rev. at 787.

241 See, e.g., Hughes to Black, May 30, 1939, Box 256, Hugo L. Black MSS, Manuscript Division, Library of Congress; Hughes to Douglas, May 30, 1939, Box 36, William O. Douglas MSS, Manuscript Division, Library of Congress.

242 See Hague v. C.I.O, 307 U.S. 496, 500 (1939) ("Mr. Justice Butler, presiding in the absence of the Chief Justice and Justice McReynolds"). Hughes was absent due to illness with a duodenal ulcer. See 2 Members Away, High Court Plans to Finish Term, Wash. Post, June 5, 1939, p. 2.

${ }^{243}$ Stone OT 1938 Docket Book at 556 lists McReynolds as "abs[ent]" for the vote on the petition for rehearing in No. 945, City \& County of Denver v. The People of the State of Colorado, while listing everyone else as voting to dismiss. Douglas Docket OT 1938 Book at 303 similarly lists no vote for McReynolds and a vote to dismiss for everyone else. Douglas OT Docket Book at 304, Stone OT 1938 Docket Book at 557, and Butler OT 1938 Docket Book at 608 also list no vote for McReynolds and a vote to dismiss for everyone else in No. 975, The Kansas Farmers' Union Royalty Co. v. Hushaw. With respect to petitions for certiorari, Douglas OT 1938 Docket Book records votes for everyone but McReynolds in No. 926, Partridge $v$. Martin, and No. 948 Townshend v. Union Trust Co. of Maryland. In none of the cases taken up at the June 3 conference is there any indication of a vote cast by 
wrote to his mother that "[t]he Justice returned to Washington after having been away for two weeks visiting his old home in Kentucky." ${ }^{244}$ This action, though hardly commendable, may not have been quite as irresponsible as Boskey's account suggests. The Court had announced on May 1 that it would adjourn for the summer on May 29, 245 and McReynolds, who was traveling to his birthplace for

McReynolds at that conference. See Butler OT 1938 Docket Book; Stone 1938 OT Docket Book; Roberts OT 1938 Docket Book; Douglas OT 1938 Docket Book. For the conference list, see Box 36, William O. Douglas MSS, Manuscript Division, Library of Congress. On June 4, with a dateline of June 3, the Times-Picayune reported that McReynolds "already has left Washington to visit relatives in Kentucky." Hughes Stricken III; Will Be Off Bench for Time, Times-Picayune, June 4, 1939, p. 25.

244 Milton Musser to Ellis Shipp Musser, June 16, 1939, Box 21, folder 4, Musser Family Papers, Utah State Archives. Musser continued, "I hope he leaves again and soon." Id.

245 Supreme Court to Quit May 29 for Summer, Wash. Post, May 2, 1939, p. 2 ("The Supreme Court announced yesterday that it will adjourn for the summer on May 29, barring unexpected developments"). It appears that the six week absence (March 4-April 15) of the Chief Justice owing to illness, compounded by the two month hiatus (February 13-April 17) between the resignation of Brandeis and the confirmation of Douglas, put the Court a bit behind in its work. Though the justices handed down thirteen decisions on February 27, see 306 U.S. at 240-397, they delivered only one more over the next month (Texas v. Florida, 306 U.S. 398 (1939), March 13). The Court handed down ten more decisions on March 27, see 306 U.S. at 436-521, but only two more on April 3, see 306 U.S. at 522-530. When the Court was restored to full strength on April 17, the justices announced twenty-one more decisions. See 306 U.S. at 531-614, 307 U.S. at 1-160. The Court announced one more decision on April 24, see 307 U.S. at 161-70, six more on May 15, see 307 U.S. at 171-218, and eight more on May 22, see 307 U.S. at 219-313. But despite handing down six more decisions on May 29, see 307 U.S. at 313-432, there remained seven more that had yet to be rendered. These included not only Coleman and its companion case from Kentucky, Chandler v. Wise, 307 U.S. 414 (1939), but also such other major cases generating multiple opinions as Hague v. C.I.O., 307 U.S. 496 (1939), U.S. v. Rock Royal Co-operative, Inc., 307 U.S. 533 (1939), and H.P. Hood \& Sons v. United States, 307 U.S. 588 (1939). Justice Douglas's files show that he was at work on an opinion concurring in the result of American Toll Bridge Co. v. Railroad Commission of California, 307 U.S. 486 (1939), every day from May 29 to June 2. See Box 37, William O. Douglas MSS, Manuscript Division, Library of Congress. Douglas eventually scrapped the opinion and simply noted his concurrence in the result. 307 U.S. at 496. The Court heard argument in twenty cases during Hughes's absence in March, see 306 U.S. at 466-601; in late April and early May, after Hughes had returned and Douglas had joined the Court, the justices heard argument or re-argument in seventeen cases. These included Coleman, Chandler, Rock Royal, Hood, O'Malley v. Woodrough, Graves v. Elliott, and United States v. Powers. See 307 U.S. at 171-588. Rock Royal and Hood were not argued until April 24-26, see 307 U.S. at 533, 588, and were not discussed in conference until May 6 . See Conference List, May 6, 1939, Box 36 William O. Douglas MSS, Manuscript Division, Library 
"a family reunion and celebration," 246 appears to have relied upon that announcement in making his plans. The clerk's letter does not supply specific dates of travel, but the Washington Post reported on June 12 that McReynolds had left his boyhood home in Elkton the preceding day in order to attend the funeral of Judge Charles $\mathrm{H}$. Robb on Tuesday, June $13 .{ }^{247}$ An absence of two weeks would place McReynolds's departure from Washington on May 30 or May 31. On June 2,1939, the Paducah Sun-Democrat ran a story with the headline "Justice McReynolds Picks Elkton Visit over Fete for King." With a dateline from Elkton on June 2, the story related that McReynolds had declined an invitation to meet the King and Queen of Great Britain at a June 8 garden party held at the British embassy in Washington "because," as he told his interviewer in Elkton, "I simply preferred to be here." 248

This evidence alone would suggest that McReynolds probably had left Washington by the time that the justices convened on May 31. The journey from Washington to Elkton is one of approximately 725 miles. McReynolds allocated two days for his return trip from Elkton to Washington for Judge Robb's funeral, so he probably would have allocated the same amount of time for his transit from Washington to Elkton. Whether he traveled by car ${ }^{249}$

of Congress. Indeed, the justices needed another conference on June 3 in order to dispose of some remaining matters. See Conference List, June 3, 1939, Box 36, William O. Douglas MSS, Manuscript Division, Library of Congress. Justice Douglas's papers contain a document, apparently prepared some time before March 27, 1939, with the heading "Proposed Schedule for Remainder of October Term, 1938." The schedule anticipates Argument days on March 27, April 17, and April 24; Recess on April 3, April 10, and May 8; and Court Sessions on May 1, May 15, May 22, and May 29. Box 36, William O. Douglas MSS, Manuscript Division, Library of Congress. Both the Proposed Schedule and the May 1 announcement of the Court's remaining calendar appear in retrospect to have been overly optimistic.

246 Justice McReynolds "Snubs" Royalty for Reunion, Chicago Daily Tribune, June 6, 1939, p. 9.

${ }^{247}$ McReynolds Coming Here, Wash. Post, June 12, 1939, p. 17.

248 Justice McReynolds Picks Elkton Visit Over Fete for King, Paducah SunDemocrat, June 2, 1939, p. 5. See also Justice McReynolds "Snubs" Royalty for Reunion, Chicago Daily Tribune, June 6, 1939, p. 9.

249 McReynolds liked to travel in his 1929 six-cylinder Buick couple convertible, and may well have journeyed by car to Elkton that year. Though he was reportedly an aggressively fast driver, he would not have covered the distance from Washington to Elkton on the roads of 1939 in a single day. On a 1936 drive from Washington to West Point - a journey of under 300 miles - McReynolds allocated two days for 
or by train, 250 if McReynolds was in Elkton early enough on June 2nd to grant an interview that would be published in Paducah's evening newspaper, then he probably would have departed Washington no later than May 31.

Any remaining doubt about McReynolds's presence at the May 31 conference is removed, however, by the June 3 dateline edition of Drew Pearson and Robert S. Allen's Washington Merry-GoRound column. There - two days before the even division in Coleman was announced - the authors reported that that McReynolds would not be present with his hardworking colleagues for the Court's June 5th session because he would be "taking things easy" in Elkton. "The Court originally had fixed its adjournment date for May 29," Pearson and Allen noted, but "under the pressure of an extra heavy docket, Chief Justice Hughes added another week to the term in order to clean up unfinished cases. Meanwhile McReynolds had arranged a reunion in Elkton and refused to change his plans notwithstanding the uncompleted calendar. He sat with the court on May 29, but the next day packed his bag and started on his vacation while his colleagues remained at their desks."251

It appears clear, therefore, that McReynolds was in fact the missing justice in Coleman. However, because the question of whether the Lieutenant Governor was eligible to vote had been briefed and argued by the parties, ${ }^{252}$ and because the original draft of Hughes's opinion had contained over five pages of text deciding the issue on the merits in favor of the officer's eligibility, ${ }^{253}$ it is hard to understand how that could have been "a new point that came up" so late

transit, stopping for the first night at Delaware Water Gap, approximately 240 miles from Washington. See Hutchinson \& Garrow at 23-27.

250 As of 1947 the trip from Washington to Cincinnati on the Baltimore \& Ohio Railroad was one of 11.5 hours. http://www.american-rails.com/cincinnatian.html. The connecting train on the Louisville \& Nashville Railroad to Guthrie, Kentucky which might have required an overnight stay in Cincinnati - would as of 1958 still have consumed another 6.5 hours. http://www.Inrr.org/Magazine/Ln_passenger_ timetable.pdf. McReynolds would then have faced a ten-mile journey to Elkton on the Guthrie \& Elkton Railroad, or possibly transportation by automobile.

251 Drew Pearson \& Robert S. Allen, McReynolds Jumps Gun on Court Associates by Taking Vacation Early, Nashville Tennessean, June 5, 1939, p. 5.

252 Brief on Behalf of Petitioner, Coleman v. Miller, at 5-13; Brief on Behalf of Respondents, Coleman v. Miller, at 1-2, 4-6.

253 Chief Justice Hughes, draft opinion in Coleman v. Miller, Box 256, Hugo L. Black MSS, Manuscript Division, Library of Congress, pp. 9-14. 
in the deliberations. More likely, it seems, is that the precise issue of whether the Lieutenant Governor's eligibility to vote presented a non-justiciable political question, which the parties did not brief or argue, was "a new point" raised by one of the justices late in the production of the opinions.

That justice appears to have been Black, who wrote in the margin of his copy of Hughes's draft that the issue of the Lieutenant Governor's eligibility presented "a political question for Congress," 254 and scribbled "by Congress though" next to Hughes's assertion that the issue presented "a federal question to be determined in deciding whether the 'legislature' has acted as required by Article V." 255 In his concurring opinion, which was joined by Justices Roberts, Frankfurter, and Douglas, Black asserted that "whether submission, intervening procedure or Congressional determination of ratification conforms to the command of the Constitution, calls for decisions by a 'political department' of questions of a type which this Court has frequently designated 'political."'256 Black went on to disapprove of "judicial review of or pronouncements ... as to whether duly authorized state officials have proceeded properly in ratifying or voting for ratification" as "judicial interference" in "matters that we believe were intrusted by the Constitution solely to the political branch of government." 257 The Amendment process, Black insisted, was "'political' in its entirety, from submission until an amendment becomes part of the Constitution, and is not subject to judicial guidance, control, or interference at any point." 258

Hughes's draft opinion made it clear that he disagreed with Black, Roberts, Frankfurter, and Douglas on the question of the justiciability of the issue of the Lieutenant Governor's eligibility, and it appears that Stone and Reed agreed with him. Justice Butler's dissenting opinion closed by observing that the question of whether the issue of the proposed amendment's vitality was non-justiciable

254 Id. at 9.

255 Id. at 10.

256307 U.S. at 457 (emphasis added).

257 ld. at 458.

258 Id. at 459 . These three passages also appear in an earlier, undated, uncirculated draft of Black's separate opinion. Box 256, Hugo Black MSS, Manuscript Division, Library of Congress. 
"was not raised by the parties or by the United States appearing as amicus curiae." Neither had that question been suggested by the Court when it ordered re-argument. It therefore would be inappropriate, Butler opined, "without hearing argument on the point," to hold that the Court lacked power to decide the question of whether the amendment was no longer subject to ratification. ${ }^{259}$ Though his opinion did not speak to the issue of the Lieutenant Governor's eligibility, Butler may well have taken a similar view of the claim that the Court should declare that issue non-justiciable without appropriate briefing and argument. In any event, it appears that Butler joined Hughes, Stone, and Reed in opposing those who supported Black's position, producing a 4-4 tie. It appears that McReynolds simply was not there to break the deadlock.

Even if McReynolds had been present, however, it is not certain that he would have cast a vote on the issue. Douglas noted in his docket book that, at the April 22nd conference, "McReynolds having voted to dismiss did not vote on the merits." ${ }^{260}$ As is suggested by the Yale Law Journal Note, which affirmed that McReynolds "could properly refuse to consider the question," it may be that the irascible justice, who had declined to vote on the merits in conference, would have simply refused to vote on this issue. He ultimately backed his friend Butler on the question of the proposed amendment's vitality, and for this it was necessary that he change his conference position - probably quite reluctantly, in light of what we know of his jurisdictional views ${ }^{261}$ - on the threshold question of standing. ${ }^{262}$ But having thus disposed of the merits on

259 Id. at 474.

260 Douglas OT 1938 Docket Book.

261 See, e.g., Melvin I. Urofsky, The Brondeis-Frankfurter Conversations, 1985 Sup. Ct. Rev. 299, 317 (Brandeis opining that "McR. cares more about jurisdictional restraints than any of them").

262 The fact that Hughes's opinion was identified as "the opinion of the Court" might suggest that McReynolds and Butler actually joined the portion of Hughes's opinion addressing the standing issue. As Hughes's May 30 letter expressed some doubt about whether "an opinion can be written for the Court," this might appear to suggest that McReynolds was present for the May 31 conference, and that he and Butler agreed to join the portion of Hughes's opinion addressing the standing question. However, Hughes also purported to write "the opinion of the Court" on the issue of the proposed amendment's continuing vitality, but Butler and McReynolds dissented from this holding, and Black, Roberts, Frankfurter, and Douglas concurred "in the result reached, but for somewhat different reasons." 307 U.S. at 457. 
the ground that the proposed amendment was no longer subject to ratification, he might not have thought it necessary or proper to reach the issue of the Lieutenant Governor's eligibility to vote. Indeed, the fact that Butler's dissenting opinion did not speak to the issue of the Kansas legislature's previous rejection of the proposed amendment may have been a concession made to conciliate McReynolds. If McReynolds would have persisted in his refusal to reach the other merits issues, it may not have mattered that he failed to attend the May 31 conference on Coleman.

Thornhill v. Alabama ${ }^{263}$ was one of several civil rights and civil liberties cases in which one or more of the justices changed position between the conference vote and the final vote on the merits. In Thornhill, the Court's holding that peaceful labor picketing was protected free speech was unanimous, but at the conference McReynolds had passed. ${ }^{264}$ In Minersville School District v. Gobitis, ${ }^{265}$ an 8-1 majority upheld a state regulation requiring students in public schools to participate in a daily ceremony involving recitation of the Pledge of Allegiance while saluting the flag. At the conference, seven of the justices had voted to sustain the measure, but Stone and Black had passed. ${ }^{266}$ The two justices ultimately resolved their

This meant that there were seven votes in favor of the disposition, but only three Hughes, Stone, and Reed - for what purported to be the "opinion of the Court" on that issue. It therefore appears that, at least with respect to the issue of the proposed amendment's continued vitality, the reported decision does not use the term "the opinion of the Court" in its current sense, but only to indicate that there was a majority for the result reached if not for the rationale articulated by Hughes's opinion. It may be that Hughes similarly regarded his opinion as "the opinion of the Court" with respect to the disposition of the standing issue, if not with respect to its analysis. It is also possible that Hughes and/or his colleagues may have considered the portion of the opinion dealing with the standing issue as "the opinion of the Court," in the sense that there were five justices who had not affirmatively indicated that they disagreed with its result or reasoning. For a recent effort to untangle the votes in and thus to determine the meaning of Coleman, see Arizona State Legislature v. Arizona Independent Districting Comm'n, (Scalia, J., dissenting), Slip Opinion at 4-6 (2015).

263310 U.S. 88 (1940).

264 Stone OT 1939 Docket Book; Reed OT 1939 Docket Book; Douglas OT 1939 Docket Book.

265310 U.S. 586 (1940).

${ }^{266}$ Stone OT 1939 Docket Book; Douglas OT 1939 Docket Book. Reed OT 1939 Docket Book contains no record of the conference vote. Murphy's conference notes record Hughes as speaking in favor of the regulation, though with some reservations. Dickson at $430-31$. 
respective uncertainties in different ways: Black joined the majority, while Stone filed a lone dissent. ${ }^{267}$ And in Missouri ex rel. Gaines v. Canada, ${ }^{268}$ the Court held that the state's system of segregated legal education violated the Equal Protection Clause. The published decision was by a vote of 6-2, with McReynolds and Butler dissenting. ${ }^{269}$ At the conference, however, Butler had been with the majority. ${ }^{270}$ The notes of Stone and Brandeis are difficult to decipher, but from Brandeis's entry it appears that Butler, Stone, and Black may have expressed a preference for some sort of "mollification." 271 In any event, Butler apparently was not satisfied by the opinion agreed upon by the other members of the conference majority, and he defected to the dissent.

The domain of criminal procedure was the site of one of the most dramatic post-conference shifts in voting. In Johnson $v$. Zerbst, ${ }^{272}$ the Court held that that the Sixth Amendment required that the Government provide counsel to federal criminal defendants who were unable to secure representation. The final decision was 6-2: Reed concurred in the judgment of reversal, McReynolds and Butler dissented, and Cardozo did not participate. At the conference, however, seven of the eight justices present had voted to affirm, with Stone passing. ${ }^{273}$ The votes of six justices changed between the conference and announcement of the decision. The change was far more modest in Nardone $v$ United States, ${ }^{274}$ where

267 McReynolds concurred in the result.

268305 U.S. 337 (1938).

${ }^{269}$ Cardozo had died and had not yet been replaced by Frankfurter.

270 Stone OT 1938 Docket Book; Roberts OT 1938 Docket Book; Brandeis OT 1938 Docket Book. Butler OT 1938 Docket Book and Reed OT 1938 Docket Book contain no record of the conference vote.

271 Brandeis OT 1938 Docket Book. Stone's notes indicate that Hughes invoked the authority of the "McCabe Case." The reference here is to McCabe v. Atchison, Topeka \& Santa Fe Railway Co., 235 U.S. 151 (1914), in which Hughes wrote the opinion of the Court holding that an Oklahoma statute that permitted rail carriers to provide sleeping and dining cars only to whites violated the Equal Protection Clause, even if there were limited demand for such accommodations by AfricanAmericans.

272304 U.S. 458 (1938).

273 Stone OT 1937 Docket Book; Butler OT 1937 Docket Book; Roberts OT 1937 Docket Book; Reed OT 1937 Docket Book. Brandeis OT 1937 Docket Book contains no record of the conference vote.

274302 U.S. 379 (1937). 
the Court upheld the suppression of evidence obtained through an illegal wiretap. The final vote was 7-2, with McReynolds and Sutherland dissenting, but at the conference vote Cardozo passed. ${ }^{275}$

Two major voting rights cases also involved interesting changes of position between conference and final decision. In Lane $v$. Wilson, ${ }^{276}$ the Court invalidated an Oklahoma statute that was designed to preserve the scheme of African-American disfranchisement that the Court had invalidated in Guinn v. United States. ${ }^{277}$ In Guinn, a unanimous Court had invalidated the Oklahoma constitution's "grandfather clause," which exempted from the state's literacy test for the suffrage those descended from persons qualified to vote before 1866 . The clause was a transparent attempt to deny the right to vote on the basis of race, and the Court struck it down as a violation of the Fifteenth Amendment. A special session of the Oklahoma legislature responded by enacting a statute requiring that persons who were eligible to vote but for the grandfather clause had to register to vote within a twelve day window in 1916 or be forever disfranchised. Lane was among those otherwise eligible, but for reasons that were disputed he was not registered during the 1916 window. When the county registrars refused to enroll him in 1934, he claimed that this deprived him of rights secured by the Fifteenth Amendment. 278

The final vote in Lane was 6-2, with McReynolds and Butler dissenting. At the conference, however, both Stone and Butler record Hughes as voting with the dissenters. ${ }^{279}$ Indeed, though Butler's notes of the conference are difficult to decipher, it appears that Hughes embraced the state's theory of the case completely. Butler records Hughes as invoking the authority of the "Giles Case," 280 i.e.,

275 Stone OT 1937 Docket Book; Butler OT 1937 Docket Book; Roberts OT 1937 Docket Book; Brandeis OT 1937 Docket Book. Brandeis has an illegible notation in Cardozo's voting column.

276307 U.S. 268 (1939). Douglas took no part in the decision.

277238 U.S. 347 (1915).

278307 U.S. at $269-72$.

279 Stone OT 1938 Docket Book; Butler OT 1938 Docket Book. Roberts OT 1938 Docket Book contains no record of the conference vote. Butler records Reed as voting both to affirm and to reverse. Reed OT 1938 Docket Book records the vote as 61 to affirm, with Butler alone in dissent and Hughes not voting. At the same time, however, he records the disposition as "Reversed."

${ }^{280}$ Butler OT 1938 Docket Book. 
Giles v. Harris, ${ }^{281}$ which the majority opinion expressly held was not controlling. ${ }^{282}$ Hughes argued that the plaintiff "Can't recover because he didn't pursue stat to [illegible]." 283 By this he presumably meant, as Frankfurter summarized the argument in his majority opinion, "that the state procedure for determining claims of discrimination must be employed before invoking a federal judiciary." 284 But here again the Court concluded that "[t]o vindicate his present grievance the plaintiff did not have to pursue whatever remedy may have been open to him in the state courts." 285 Finally, Hughes appears to have found the statute in question unproblematic because it was facially neutral. Butler records him as stating that it was "applicable to negroes and whites alike."286 Here again, the opinion that Hughes ultimately joined rejected this argument. ${ }^{287}$ The Chief Justice appears to have acquiesced in the majority's judgments on each of the three principal issues presented by the case.

Finally, United States v. Classic, ${ }^{288}$ a case handed down in the waning days of Hughes's tenure, upheld the convictions of Louisiana Commissioners of Elections under the Enforcement Act of 1870 for fraudulently tabulating the results of a Democratic primary election for Congress. At the conference, Black passed, and Hughes did not participate. All of the other justices voted to reverse. ${ }^{289}$ But between

281189 U.S. 475 (1903) (denying relief to African-Americans seeking an order requiring voting registrars in Montgomery, Alabama to enroll their names on the voting lists of the county).

282307 U.S. at 267-69.

283 Butler OT 1938 Docket Book.

284307 U.S. at 272.

285307 U.S. at 274.

286 Butler OT 1938 Docket Book.

287307 U.S. at $275-77$.

288313 U.S. 299 (1941). Hughes took no part in the decision.

289 Murphy OT 1940 Docket Book; Douglas OT 1940 Docket Book. Reed OT 1940 Docket Book contains no record of the conference vote. Hughes stated at the outset of the discussion that, "As I was counsel in the Newberry case [Newberry v. United States, 256 U.S. 232 (1921), holding that Congress had no power to regulate primary elections], I prefer to have it started by Justice Stone." Dickson at 834. Murphy wrote in his entry that Hughes "did not vote." Roberts OT 1940 Docket Book records Hughes and Black as not voting, and everyone else voting to reverse. He has a mark in the reverse column for Hughes, but it appears to be a crossed-out vote. Stone OT 1940 Docket Book records the vote as unanimous, with both Hughes and 
the conference and the final decision, Black resolved his doubts in favor of dissent, and Douglas and Murphy defected from the conference majority to join him on the grounds that the statute under which the defendants had been convicted did not apply to primary elections. ${ }^{290} \mathrm{~A}$ case that at conference seemed likely to produce unanimity was thus decided by the narrow margin of 4-3.

\section{REASSIGNMENTS}

After Justice Willis Van Devanter's retirement at the end of the 1936 Term, the number of reassignments per Term remained rather small. What few transfers there were often resulted from a mid-Term retirement, a recusal, a post-conference voting shift altering the case's outcome, or a disagreement over rationale. During the 1937 Term, Roberts took two tax cases from Cardozo, ${ }^{291}$ and also relieved Black of a controversy over federal jurisdiction. ${ }^{292}$ In addition, Brandeis took from Roberts a case in which the latter justice ultimately did not participate. ${ }^{293}$ The following year, McReynolds took two cases from Frankfurter, ${ }^{294}$ and Stone took two more from the retiring

Black voting, but records no vote for himself. The Murphy and Roberts accounts corroborate Douglas's notes of the conference. See David M. Bixby, The Roosevelt Court, Democratic Ideology, and Minority Rights: Another Look at United States v. Classic, 90 Yale L.J. 741, 797 (1981). On the return of Stone's first circulated draft, Hughes wrote, "I think I should not take part." On the second he wrote, "Please note that I took no part." Chief Justice Hughes, Returns of United States v. Classic, Box 66, Harlan Fiske Stone MSS, Manuscript Division, Library of Congress.

290 Bixby at 799-803.

291 No. 48, U.S. v. Andrews, and No. 262, U.S. v. Garbutt Oil Co. Butler OT 1937 Docket Book; Stone OT 1937 Docket Book; Roberts OT 1937 Docket Book; Brandeis OT 1937 Docket Book.

292 No. 274, St. Paul Mercury Indemnity Co. v. Red Cab Co. Butler OT 1937 Docket Book; Stone OT 1937 Docket Book; Roberts OT 1937 Docket Book; Brandeis OT 1937 Docket Book.

293 No. 33, Helvering v. Bashford. Stone OT 1937 Docket Book; Roberts OT 1937 Docket Book. The initial conference vote was 5-4 to affirm, with Roberts, Hughes, McReynolds, Sutherland, and Butler in the majority, and Brandeis, Stone, Cardozo, and Black dissenting. Roberts later recused himself, and on a second vote Hughes shifted camps to join the former dissenters, while Cardozo was absent. The ultimate disposition was 5-3 for reversal, with McReynolds, Sutherland, and Butler dissenting, and the ailing Cardozo taking no part. 302 U.S. 454 (1938).

294 No. 65 , Fairbanks v. U.S., and No. 548, Smith v. The Ferncliff. Butler OT 1938 Docket Book; Stone OT 1938 Docket Book. 
Brandeis. ${ }^{295}$ Stone also assumed responsibility for two cases previously assigned to colleagues who ended up dissenting. ${ }^{296}$ No. 509, Driscoll v. Edison Light \& Power Co., appears initially to have been assigned to Frankfurter, ${ }^{297}$ but was ultimately written by Reed, with the former professor instead writing a concurring opinion objecting to the majority's rationale. ${ }^{298}$ And when the Court initially voted in October of 1938 to reverse the lower court in No. 14, Chandler v. Wise, the opinion had been assigned to Brandeis. ${ }^{299}$ The case was reargued in the spring of 1939 after Brandeis had retired, however, and Hughes ultimately wrote the opinion dismissing rather than reversing the case..$^{300}$

The 1939 Term recorded only three reassignments: one from Reed to Douglas, ${ }^{301}$ one from Frankfurter to Douglas, ${ }^{302}$ and one from Murphy to Hughes. ${ }^{303}$ And during Hughes's final Term as Chief Justice, only five cases changed hands. Murphy took one case from Hughes, ${ }^{304}$ and he relieved Stone of another in which the latter ultimately took no part. ${ }^{305}$ Stone reciprocated by taking a case from

295 No. 158, Pacific Employers Ins. Co. v. Industrial Accident Commission of California, Butler OT 1938 Docket Book; Stone OT 1938 Docket Book; Nos. 252-256, Joseph S. Finch \& Co. v. McKittrick, Roberts OT 1938 Docket Book.

296 No. 339, Curry v. McCanless, initially was assigned to Butler, who ultimately dissented with Hughes, McReynolds, and Roberts. Stone OT 1938 Docket Book. No. 372 , Graves v. Elliott, initially was assigned to Hughes, who ultimately wrote a dissent joined by McReynolds, Butler, and Roberts. Stone OT 1938 Docket Book. The conference vote on January 14, 1939 was 4-3, with the eventual dissenters comprising the majority. Cardozo had not yet been replaced by Frankfurter, and Brandeis, who would soon retire, did not vote. Roberts OT 1938 Docket Book; Butler OT 1938 Docket Book; Stone OT 1938 Docket Book. The case was reargued in late April, after both Frankfurter and Douglas had been confirmed, and the votes of the new justices changed the outcome. 307 U.S. 383 (1939).

297 Butler OT 1938 Docket Book.

298307 U.S. 104, 122 (1939) (Frankfurter, J., concurring).

${ }^{299}$ Stone OT 1938 Docket Book.

300307 U.S. 474 (1939). Douglas OT 1938 Docket Book has no record of reassignments.

301 No. 386, Dickinson Industrial Site, Inc. v. Cowan. Stone OT 1939 Docket Book; Murphy OT 1939 Docket Book. Douglas's clerk records that "his concurring opinion became opin. of Court." Douglas OT 1939 Docket Book.

302 No. 384, Helvering v. Wood. Stone OT 1939 Docket Book.

${ }^{303}$ No. 559, Helvering v. Price. Stone OT 1939 Docket Book.

${ }^{304}$ No. 74, Stoner v. New York Life Ins. Co. Stone OT 1940 Docket Book.

${ }^{305}$ No. 90, Benitez Sampayo v. Bank of Nova Scotia. Roberts OT 1940 Docket Book. 
Murphy. ${ }^{306}$ Finally, Stone also took control of two cases that initially had been assigned to McReynolds, ${ }^{307}$ but from which the latter ultimately dissented along with Hughes and Roberts. ${ }^{308}$

\section{CONCLUSION}

In addition to the information that they provide about the Court's deliberations in particular cases, the docket books of the late Hughes Court justices teach us some larger lessons. First, the docket books show that the few instances in which Hughes reassigned cases typically involved a mid-term retirement, a recusal, a post-conference voting shift, or a disagreement over rationale. Second, they also illuminate the civil liberties views of Hughes and Cardozo. Cardozo publicly dissented from a number of decisions reversing criminal convictions, ${ }^{309}$ but his passing conference vote in Nardone $v$. United

306 No. 727, Shamrock Oil \& Gas Corp. v. Sheets. Roberts OT 1940 Docket Book.

307 The first case was No. 27, Helvering v. Horst. Stone OT 1940 Docket Book; Murphy OT 1940 Docket Book. The vote at the October 29, 1940 conference had been 7-2 to affirm, with Black and Douglas dissenting. Stone OT 1940 Docket Book; Murphy OT 1940 Docket Book; Roberts OT 1940 Docket Book. Roberts records a "Revote" on November 15, in which Stone, Reed, and Frankfurter changed their votes, and Murphy passed. Roberts OT 1940 Docket Book; see also Stone 1940 OT Docket Book. Murphy ultimately joined the new majority for dismissal. 311 U.S. 112 (1940). The second case was No.205, Helvering v. Eubank, in which a similar voting pattern was observed. Stone OT 1940 Docket Book; Murphy OT 1940 Docket Book; Roberts OT 1940 Docket Book. The vote at the October 29 conference was 5-4 to affirm, with Reed, Frankfurter, Douglas, and Murphy dissenting. A "Revote" was held on November 15, where Black and Stone changed their votes to reverse. Stone records Murphy as again passing, while Roberts records him as holding to his original vote to reverse. Roberts OT 1940 Docket Book; Stone OT 1940 Docket Book. In either event, Murphy ultimately joined the majority to reverse. 311 U.S. 122 (1940). Douglas OT 1940 Docket Book records that in these two cases "Dissenting opinion by Stone, J. became opinion of Court."

${ }^{308}$ Helvering v. Eubank, 311 U.S. 122, 125 (1940) (McReynolds, J., dissenting); Helvering v. Horst 311 U.S. 112, 120 (1940) (McReynolds, J. dissenting).

${ }^{309}$ See, e.g., Sgro v. United States, 287 U.S. 206, 212 (1932) (Stone and Cardozo dissent from opinion holding search unconstitutional); Grau v. United States, 287 U.S. 124, 129 (1932) (Stone and Cardozo dissent from opinion holding search unconstitutional); see also Palko v. Connecticut, 302 U.S. 319 (1937) (Cardozo writes and Stone joins opinion holding that the Double Jeopardy Clause does not apply to state criminal prosecutions); United States v. Murdock, 290 U.S. 389, 398 (1933) (Stone and Cardozo dissent from opinion affirming that it was reversible error for the trial judge to inform the jury of his view that the accused was guilty beyond a reasonable doubt). 
States suggests that he was even less favorably inclined toward claims of the accused than his published vote would appear to indicate. And assuming that Butler's notes on the conference discussion in Lane v. Wilson faithfully record the Chief Justice's remarks, Hughes was less inclined to strong protections of voting rights than his vote in the published opinion would suggest. His passing vote at the Cantwell $v$. Connecticut conference and his dissenting conference vote in Lanzetta $v$. New Jersey similarly complicate his civil liberties record as reflected in the U.S. Reports.

The published decisions are not nearly as misleading concerning the civil rights and civil liberties views of Cardozo and Hughes, however, as they are of those of McReynolds. Though he ultimately joined majorities favoring such claims in many cases, at conference he dissented from dispositions that he would publicly join in Chambers v. Florida, Lanzetta v. New Jersey, and Pierre v. Louisiana. In addition, at conference he passed in Thornhill v. Alabama, Lovell $v$. Griffin, Weiss v. United States, and Smith v. Texas. Indeed, it seems that late in his tenure, as the personnel of the Court changed and he became increasingly isolated in his views, the aging and, as one of his clerks charged, lazy ${ }^{310}$ Justice may not have been preparing for conference as assiduously as he might have. He seemed to pass more frequently at conference votes, and as he remarked when his turn came to speak at the Consolidated Edison conference in 1939, he had "nothing to say."

The docket books also reveal considerable fluidity between the initial conference vote and the final vote on the merits among the justices of the late Hughes Court. First, there were eight instances of defection in major cases. McReynolds was responsible for $37.5 \%$ of these, departing from passing conference votes in Erie, Mountain Producers, and on the issue of the timeliness of ratification in Coleman. Five other justices contributed one defection $(12.5 \%)$ each. Butler departed from a vote with the conference majority in Gaines, as did Douglas and Murphy in Classic. Meanwhile, Stone and Black abandoned passing conference votes in favor of published dissents in Gobitis and Classic, respectively. Thus, three $(37.5 \%)$ of these defections were of the strong variety, and five (62.5\%) of the weak variety. Second, there were instances of

310 See Hutchinson \& Garrow at 141-42, 189-92, 227. 
post-conference shifts that created majorities for a disposition for which none had materialized at conference. Stone ultimately broke a 4-4 conference deadlock in Rock Royal, while in Zerbst six justices changed positions between the conference vote and the final vote on the merits to transform a conference majority to affirm into a decision to reverse. Third, there was an instance of justices switching places between the 5-4 vote at the conference and the 5-4 final vote on the merits that did not alter the Court's disposition of the relevant issue. It is difficult to know whether McReynolds was acquiescing or defecting on the standing issue in Coleman, because we do not know whether he changed his vote before or after Roberts defected from the conference majority on that issue. But though this trading of places changed the composition of the narrow majority, it did not alter the judgment. Fourth, there were instances in which a focus on the conference vote is not sufficiently nuanced to capture the texture of a case of acquiescence adequately. To be sure, Black and Reed changed their conference votes concerning the disposition in Erie, but their conference remarks indicate that they subscribed to much of the broader rationale on which Brandeis's opinion ultimately rested. Similarly, Black and perhaps Douglas and Stone did not persuade their colleagues to overrule both Miles v. Graham and Evans v. Gore in $O^{\prime} M a l l e y$, and they ultimately joined an opinion overruling only the former case. But this acquiescence in rationale did not require any change in their conference votes regarding the case's disposition.

The most common form of vote fluidity on the late Hughes Court, however, was acquiescence. The thirty-four unanimous decisions discussed here provide a rough indication of this: while sixteen $(47.1 \%)$ of these cases also were unanimous at conference, eighteen $(52.9 \%)$ were not. If we eliminate from this category unanimous cases decided per curiam and without full opinion, the respective percentages become even more striking. Of the thirty unanimous cases decided by full opinion, twelve (40\%) also were unanimous at conference, while eighteen $(60 \%)$ were not. ${ }^{311}$ This

311 If we also eliminate Hale v. Kentucky, which was decided per curiam with a full opinion, the respective percentages become $37.9 \%$ and $62.1 \%$. 
observation is consistent with earlier studies finding that conformity voting is the most common form of vote fluidity. ${ }^{312}$

The frequency with which each of the justices acquiesced in the views of the majority is worthy of note. The notoriously cantankerous and disagreeable Justice McReynolds was actually the member of the Court most likely to acquiesce in a decision in order to produce unanimity. Of the eighteen unanimous decisions discussed here that were not unanimous at conference, McReynolds acquiesced in thirteen (72.2\%). By contrast, Hughes acquiesced in seven $(38.9 \%)$, Butler and Roberts in four (22.2\%) each, and Brandeis and Stone in one $(5.6 \%)$ each. Of the Roosevelt appointees, only the courtly Stanley Reed, who acquiesced in two decisions (10.1\%), suppressed his dissenting conference votes to produce unanimity in any of these cases. Of these thirty-two instances of acquiescence, twenty $(62.5 \%)$ were of the strong variety and twelve $(37.5 \%)$ were of the weak variety. ${ }^{313}$

Acquiescence in non-unanimous cases was, understandably, less common. Hughes, Stone, and Roberts each did so twice (20\%), and McReynolds, Butler, Cardozo, and Black once (10\%) each. Of these

312 See, e.g., Maltzman \& Wahlbeck, 90 Am. Pol. Sci. Rev. at 590-91 (finding that justices were more likely to move from a dissenting conference vote to the majority than to defect from the conference majority); Brenner \& Dorff, $4 \mathrm{~J}$. Theoretical Politics at 198 (finding that movement from conference minority to ultimate majority is the most frequent type of vote fluidity); Brenner, $26 \mathrm{Am}$. J. Pol. Sci. at 389 (finding that $68 \%$ of the cases in which there was vote fluidity resulted in an increase in the size of the majority); Brenner, $24 \mathrm{Am}$. J. Pol. Sci. at 531, 534 ("justices are more likely to switch from the minority or nonparticipation at the original vote to the majority position at the final vote than to shift in the opposite direction... Clearly, some of the justices, once they have lost at the original vote or failed to participate in that vote, are willing to conform to the opinion of the court's majority and vote with them at the final vote. Indeed, over three-quarters of the vote changes moved in a consensus direction").

313 Six of McReynolds's thirteen acquiescences in ultimately unanimous cases were strong (Lowden, Waterman, Pierre, Lanzetta, Chambers, and Falcone), while seven were weak (Alabama Power, Duke Power, Mackay Radio, Ford Motor, Weiss, Smith v. Texas, and Lovell). Hughes acquiesced strongly in three unanimous decisions (Lowden, Waterman, and Lanzetta), and weakly in four (Darby, Opp, Cantwell, and Pullman). Each of Butler's four acquiescences in unanimous decisions was strong (Mackay Radio, Ford Motor, Pierre, and Lovell). Roberts acquiesced strongly in three unanimous cases (Lowden, Waterman, and Falcone), and weakly in one (Pullman). Brandeis's acquiescence in Barnwell Bros. was strong, as was Stone's in Lanzetta. Reed's acquiescences in both Chambers and Perkins were strong. It is also possible, though not certain, that Frankfurter acquiesced in Falcone. 
ten instances of acquiescence, only three (30\%) were of the strong variety and seven (70\%) were of the weak variety. ${ }^{314}$ Thus, of these forty-two instances of acquiescence in major cases decided by the late Hughes Court, ${ }^{315}$ twenty-three $(54.8 \%)$ were of the strong variety and nineteen (45.2\%) of the weak variety. An examination of the breakdown of these instances of acquiescence reveals an interesting and previously hidden irony found in the juxtaposition of the public and private conduct of the justices. Those who were most frequently found in the dissenting column in the Court's published reports were also those who most often acquiesced in the judgments of their colleagues in major cases. During the 1939 and 1940 Terms, the justices most like to dissent were McReynolds (22\%), Roberts (18\%), and Hughes (12\%). ${ }^{316}$ Of the forty-two instances of acquiescence in major cases, by contrast, McReynolds, who served for approximately three and a half of the four Terms, was alone responsible for $33.3 \%$, recording fourteen in all. Hughes, who served for the entire period, accounted for nine (21.4\%). Roberts, who served for the entire period, accounted for six instances (14.3\%), while Butler, who served for only two full Terms, accounted for five $(11.9 \%)$. Stone, who served for the entire period, accounted for three $(7.1 \%)$, while Reed, who served for approximately three and a half of the Terms, accounted for two (4.8\%). Brandeis, who served for about one and a half of the Terms, and Cardozo, who did not sit for any cases argued after December of 1937, each acquiesced in one (2.4\%) of these cases - the same number in which Black acquiesced over four full Terms. No instances of acquiescence in these cases were recorded for Sutherland, who served for only a little over three months of the 1937 Term; Douglas, who served a little over two of the Terms; Murphy, who served for about one and a

314 Hughes acquiesced strongly in Lane and weakly in Gerhardt. Stone acquiesced weakly in Brush and strongly on the merits issue in Coleman. Roberts acquiesced weakly in Fainblatt and strongly on the merits issue in Coleman. The acquiescences of McReynolds in Thornhill, Butler in Carolene Products, Cardozo in Nardone, and Black in Gobitis were all of the weak variety.

${ }^{315}$ For reasons explained above, I exclude from this number the voting shifts of Black and Reed in Erie, the acquiescence in rationale by Black and perhaps by Stone and Douglas in O'Malley, and McReynolds's shift with respect to the standing issue in Coleman.

${ }^{316} \mathrm{C}$. Herman Pritchett, Divisions of Opinion among Justices of the U.S. Supreme Court, 1939-1941, 35 Am. Pol. Sci. Rev. 890, 891 (1941). 
half of the Terms; and possibly Frankfurter, who served for approximately two and a half of the Terms. ${ }^{317}$ The fact that McReynolds was the late Hughes Court justice by far the most likely to acquiesce in major decisions echoes Professor Saul Brenner's finding that on the Vinson Court "extreme justices [were] most likely to be closer to the mean at the final vote than at the original vote," because "extreme justices are likely to lose more often at the original vote." 318

317 Frankfurter may have acquiesced in Falcone, though the evidence from the docket books is conflicting. See supra, n. 123.

${ }^{318}$ Saul Brenner, Ideological Voting on the Vinson Court: A Comparison of Original \& Final Votes on the Merits, 22 Polity 157, 163 (1989). An examination of these cases also provides some indication of the comparative success of the justices in preparing opinions that would attract colleagues who had dissented or passed at conference. There were eighteen major cases that became unanimous after a divided conference vote. Of these, Stone (Barnwell Bros., Lowden, Darby, Falcone) and Black (Waterman Steamship, Pierre, Smith v. Texas, Chambers v. Florida) each wrote four (22.2\%), Hughes (Ford Motor, Lovell, Perkins v. Elg) and Roberts (Mackay Radio, Cantwell, Weiss) each wrote three (16.7\%), Sutherland (Alabama Power, Duke Power) wrote two (11.1\%), and Butler (Lanzetta) and Frankfurter (Pullman) each wrote one (5.6\%). Neither Brandeis, Cardozo, Reed, nor Murphy was responsible for any of these decisions. This phenomenon can also be examined by looking at the percentage of unanimous major opinions authored by a justice that were not unanimous at conference. Here Sutherland (2/2), Roberts $(3 / 3)$, Black $(4 / 4)$, and Frankfurter (1/1) all tied at $100 \%$. Stone came next at $66.7 \%(4 / 6)$, while Hughes (3/ $6)$ and Butler (1/2) each tied at $50 \%$. The fraction for all other justices contained a zero in either the numerator (McReynolds, Brandeis, Cardozo, Reed, Douglas, Murphy) or the denominator (Brandeis, Cardozo, Murphy).

These data also should be viewed in light of divided major decisions in which the author failed to increase the size of the conference majority. Excluding Hague, for which there was no majority opinion, there were twenty-six such cases. Neither McReynolds, Brandeis, Sutherland, Butler, Black, nor Murphy wrote any of these. Hughes was the author of ten (38.5\%) (Santa Cruz Fruit, Consolidated Edison, Fansteel, Currin, Electric Bond \& Share, Bekins, Morgan II, Mountain Producers, Coleman, Gaines); Roberts wrote seven (26.9\%) (Schneider, Sands, New Negro Alliance, Lauf, Mulford, Tennessee Electric, Eisenberg); Stone wrote four (15.4\%) (Columbian Enameling, Apex Hosiery, Connecticut General, Classic); Reed wrote two (7.7\%) (Hood, Madden); and Cardozo (Palko), Frankfurter (Rowan \& Nichols), and Douglas (Sunshine Anthracite Coal) each wrote one (3.8\%).

Finally, one should also consider cases in which the author of an opinion managed to attract additional votes, but failed to achieve unanimity. Stone did so in four of twelve such cases (Carolene Products, Gerhardt, O'Keefe, Fainblatt); Frankfurter did so in three (O'Malley, Gobitis, Lane); and Brandeis (Erie), Sutherland (Brush), Roberts (Nardone), Reed (Rock Royal), and Murphy (Thornhill) in one each. Neither Hughes, McReynolds, Butler, Cardozo, Black, nor Douglas accounted for any such cases. 
The fact that the most senior justices - McReynolds, Hughes, Roberts, Butler, and Stone - were those who most frequently acquiesced in the conference majority's judgment in major cases also indicates that newcomers to the late Hughes Court did not experience the kind of freshman effect with respect to voting fluidity that some scholars have found on other Courts. The late Hughes Court welcomed five freshman justices: Black, Reed, Frankfurter, Douglas, and Murphy. As mentioned above, Reed acquiesced strongly in Chambers and Perkins, and Black acquiesced weakly in Gobitis. With the possible exception of Frankfurter, who may have acquiesced in Falcone, there were no other instances of acquiescence in a major case by any of these freshman justices on the late Hughes Court. ${ }^{319}$

By contrast, the justices who remained from the early and middle years of the Hughes Court, many of whom were holdovers from the Taft and/or White Courts, continued to aspire to the high rates

319 Further research will be necessary to determine whether the late Hughes Court justices manifested greater degrees of vote fluidity or more of a freshman effect in nonsalient cases than are manifested in the cases examined here. Some studies of voting fluidity conclude that "justices were no more likely to change their votes in important, or salient, cases than in those of lesser importance." Hagle \& Spaeth, 44 Western Political Quarterly at 124. See also Maltzman \& Wahlbeck, 90 Am. Pol. Sci. Rev. at 589 (finding that "justices are not less likely to switch in salient cases"); Brenner, Hagle, \& Spaeth, The Defection of the Marginal Justice, 42 Western Political Quarterly 409 (concluding that the defection of the marginal member of the minimum winning coalition on the Warren Court is best explained not by the importance of the case, but instead by that justice's ideological proximity to members of the dissenting coalition and, secondarily, to that justice's relative lack of competence). Other studies conclude that acquiescence was in fact more likely to occur in cases that were not "salient." Dorff \& Brenner, 54 J. Politics at 772, 773; Brenner, Hagle, \& Spaeth, 23 Polity 309. Compare Brenner, 24 Am. J. Pol. Sci. at 530 (finding that percentage of total vote switches was no greater in "nonmajor" than in "major" cases, but that vote switches occurred in a higher percentage of "nonmajor" cases); Brenner, 26 AM. J. POL. SCl. at 389 (reaching similar conclusions with a different data set). Similarly, Paul Freund reported that, "As far as I could make out, [Cardozo's] disagreements [with the majority in conference] - this being his first full term on the Court - derived from the fact that in New York he had been accustomed to a rather different set of procedural rules and substantive rules intermeshed with procedure, so that some things which were decided one way in the federal courts would have been decided differently in New York," and that this is what may have accounted for the Justice's allegedly frequent changes of vote between the conference and the final vote on the merits. Freund, 26 Ohio St. L. J. at 227 . This suggests the possibility that in some instances a greater degree of freshman vote fluidity might be exhibited in less salient cases. 
of unanimity that their predecessors had achieved. Taft is famous for his "consuming ambition" to "mass the Court" - to build unanimity so as to give "weight and solidity" to its decisions. ${ }^{320}$ The Taft Court achieved unanimity in a remarkable percentage of its cases. For the 1921-1928 Terms, $84 \%$ of the Court's published opinions were unanimous; ${ }^{321}$ taking into account all of its decisions for the entirety of Taft's tenure, the unanimity rate was $91.4 \% .^{322}$ This rate of unanimity was in line with the rates achieved by the White Court, on which McReynolds, Brandeis, and Hughes each had served, ${ }^{323}$ and the attitudes formed under White and his predecessors appear to have contributed to the persistence of this phenomenon. Taft discouraged dissents, believing that most of them were displays of egotism that weakened the Court's prestige and contributed little of value. ${ }^{324}$ As a consequence, he worked hard to minimize disagreement, often sacrificing the expression of his own personal views. ${ }^{325}$ Van Devanter shared Taft's distaste for public displays of discord, and strongly lobbied his colleagues to suppress their dissenting views. ${ }^{326}$ Butler similarly regarded dissents as exercises of "vanity" that "seldom aid us in the right development or statement of the law," and instead "often do harm." 327 He therefore commonly "acquiesce[d] for the sake of harmony \&

320 Alpheus Thomas Mason, William Howard Taft: Chief Justice 198 (Simon \& Schuster, New York, 1965); Alpheus Thomas Mason, The Supreme Court From Taft to Warren 57 (L.S.U., Baton Rouge, 1958); Alpheus Thomas Mason, The Chief Justice of the United States: Primus Inter Pares, 17 J. Pub. L. 20, 31-32 (1968).

321 Post, 85 Minn. L. Rev. at 1309.

322 Lee Epstein, Jeffrey A. Segal, Harold J. Spaeth, \& Thomas Walker, The Supreme Court Compendium: Data, Decisions, and Developments 147, 161 (C.Q., Washington, D.C., 1994).

323 Post, 85 Minn. L. Rev. at 1310.

324 Post, 85 Minn. L. Rev. at 1310-11, 1356; Mason, William Howard Taft at 198; William Howard Taft to Harlan F. Stone, Jan. 26, 1927, Box 76, Harlan Fiske Stone MSS, Manuscript Division, Library of Congress, quoted in Walter F. Murphy, Elements of Judicial Strategy 47 (Univ. of Chicago, Chicago, 1964).

3252 Henry F. Pringle, The Life and Times of William Howard Taft 1049 (Farrar \& Rinehart, New York, 1939) (Taft "shrank from all dissents, including his own"); Post, 85 Minn. L. Rev. at 1311-12.

326 Urofsky, 1985 Sup. Ct. Rev. at 330; Post, 85 Minn. L. Rev. at 1318, 1340, 1341, 1343.

327 Henry J. Abraham, The Judicial Process 214-15 (Oxford, New York, 2d. ed. 1968); Murphy at 52; Post, 85 Minn. L. Rev. at 1340. 
the Court." ${ }^{328}$ McReynolds and Sutherland expressed similar views, and suppressed dissenting opinions accordingly. ${ }^{329}$ Even the "great dissenters," Holmes and Brandeis, believed that dissents should be aired sparingly, and often "shut up," as Holmes liked to put it, when their views departed from those of their colleagues. ${ }^{330}$

Like Taft, Hughes "sought to present a united Court to the public," ${ }^{331}$ frequently suppressing his own views for the sake of unanimity. Hughes "believed that unanimity of decision contributed to public confidence in the Court," and "[e]xcept in cases involving matters of high principle, he willingly acquiesced in silence rather than expose his dissenting views." 332 As he wrote on his return of one of Stone's draft opinions, "I choke a little at swallowing your analysis, still I do not think it would serve any useful purpose to expose my views." 333 In his efforts "to find common ground upon which all could stand," Hughes "was willing to modify his own

328 Post, 85 Minn. L. Rev. at 1341-43.

329 Post, 85 Minn. L. Rev. at 1341-44; James C. McReynolds to Harlan F. Stone, Apr. 2, 1930, Box 76, Harlan Fiske Stone MSS, Manuscript Division, Library of Congress, quoted in Corley, Steigerwalt, \& Ward, $38 \mathrm{~J}$. Sup. Ct. Hist. at 30; Murphy at 52-53.

330 Urofsky, 1985 Sup. Ct. Rev. at 327, 328, 330; Post, 85 Minn. L. Rev. at 1341-42, 1344-46, 1349-51; Mason, Taft to Warren at 58 ("For the sake of harmony staunch individualists such as Holmes, Brandeis, and Stone, though disagreeing, would sometimes go along with the majority"); Northern Securities Co. v. United States, 193 U.S. 197, 400 (1904) (Holmes, J., dissenting) ("I think it useless and undesirable, as a rule, to express dissent"); Alexander M. Bickel, The Unpublished Opinions of Mr. Justice Brandeis 18 (Belknap, Cambridge, Mass., 1957) ("Can't always dissent,' [Brandeis] said ....'I sometimes endorse an opinion with which I do not agree.")

331 Epstein, Segal, \& Spaeth, 45 Am. J. Pol. Sci. at 365. See also O'Brien, Institutional Norms, at 98.

332 David J. Danelski \& Joseph S. Tulchin, eds., The Autobiographical Notes of Charles Evans Hughes xxvi (Harvard, Cambridge, Mass., 1973).

333 Charles Evans Hughes to Harlan Fiske Stone, Nov. 4, 1939, accompanying Chief Justice Hughes, Return of Sanford v. Commissioner of Internal Revenue, Box 65, Harlan Fiske Stone MSS, Manuscript Division, Library of Congress. On his return, Justice Roberts wrote, "I do not agree; but as this is a mere question of construing a tax statute, I shall say nothing unless somebody else 'hollers.' I'Il let you know if I want you to note a dissent." Justice Roberts, Return of Sanford v. Commissioner of Internal Revenue, Box 65, Harlan Fiske Stone MSS, Manuscript Division, Library of Congress. On his return, Justice McReynolds wrote, "Alas, no - Ten pages of added confusion!" Justice McReynolds, Return of Sanford v. Commissioner of Internal Revenue, Box 65, Harlan Fiske Stone MSS, Manuscript Division, Library of Congress. In the end, however, neither of these justices dissented. The published opinion is unanimous. 
opinions to hold or increase his majority; and if this meant he had to put in some disconnected thoughts or sentences, in they went." 334 And while Hughes dissented at a higher rate as Chief Justice than had White or Taft, he did so at a much lower rate than would Stone, Fred Vinson, or Earl Warren. ${ }^{335}$

A variety of factors may have contributed to what Dean Robert Post calls this "norm of acquiescence." ${ }^{336}$ Here I wish to highlight just a few. First, the literature of the period illustrates among the bench and bar a widely-held aversion to dissents as excessively self-regarding, and as weakening the force of judicial decisions by unsettling the law. ${ }^{337}$ This conviction found expression in Canon 19 of the American Bar Association's Canons of Judicial Ethics, which exhorted judges not to "yield to pride of opinion or value more highly his individual reputation than that of the court to which he should be loyal. Except in cases of conscientious difference of opinion on fundamental principle, dissenting opinions should be discouraged in courts of last resort." Instead, "judges constituting a court of last resort" were admonished to "use effort and selfrestraint to promote solidarity of conclusion and the consequent influence of judicial decision." 338 Taft was the chair of the

334 Danelski, The Influence of the Chief Justice, at 174.

335 In cases decided by written opinion, White dissented in $1.35 \%$, Taft in $0.93 \%$, Hughes in $2.24 \%$, Stone in $13.49 \%$, Vinson in $12.44 \%$, and Warren in $12.13 \%$. S. Sidney Ulmer, Exploring the Dissent Patterns of the Chief Justices: John Marshall to Warren Burger, in Sheldon Goldman \& Charles M. Lamb, eds., Judicial Conflict and Consensus: Behavioral Studies of American Appellate Courts 53 (Univ. of Kentucky, Lexington, Ky., 1986).

336 Post, 85 Minn. L. Rev. at 1344.

337 Post, 85 Minn. L. Rev. at 1344, 1348-49, 1354, 1356-57; Evan A. Evans, The Dissenting Opinion - Its Use and Abuse, 3 Mo. L. Rev. 120, 123-26 (1938) (quoting various criticisms of dissents made by members of the bench and bar); Alex Simpson, Jr., Dissenting Opinions, 71 U. Pa. L. Rev. 205, 205-06 (1923) quoting various professional criticisms of dissenting opinions); William A. Bowen, Dissenting Opinions, 17 Green Bag 690, 693 (1905) ("the Dissenting Opinion is of all judicial mistakes the most injurious"). See also Ulmer, Exploring the Dissent Patterns, at 50-51 ("dissent diminishes the image of monolithic solidarity, which allegedly enhances respect for the Court and obedience to its mandates.")

${ }^{338}$ ABA Canons of Judicial Ethics, Canon 19 (1924), in Lisa L. Milord, The Development of the ABA Judicial Code 137 (A.B.A., Chicago, 1992). In 1972, the American Bar Association replaced the Canons with a Code of Judicial Conduct, which does not contain a provision similar to Canon 19. Wahlbeck, Spriggs II, \& Maltzman, 27 American Politics Quarterly at 508 n.1. 
committee that drafted the Canons, and Sutherland was a committee member before his appointment to the Court. ${ }^{339}$ Second, the norm of acquiescence promoted a collegiality and reciprocity among the justices that smoothed over potential conflicts and avoided alienating colleagues whose support one might need in future cases..$^{340}$ Third, during this period nearly all of the justices had only one clerk rather than the four that justices typically have today, and most of the justices wrote their own opinions. ${ }^{341}$ With such comparatively limited resources at their disposal, the cost of preparing a dissenting opinion was considerably higher. ${ }^{342}$

The unanimity rates of the early Hughes Court were remarkably similar to those of the White and Taft Courts. For the 1930 Term the rate was 89.2\%; for the 1931 Term it was 82.7\%; for the 1932 Term it was $83.9 \%$; and for the 1933 Term it was $83.5 \%$. Even during the height of the Court's encounter with the New Deal, unanimity rates remained robust: $85.9 \%$ for the 1934 Term; $82.1 \%$ for the fractious 1935 Term; and $79.2 \%$ during the 1936 Term. With the

339 Post, 85 Minn. L. Rev. at 1284 n.55.

340 Post, 85 Minn. L. Rev. at 1345. See also Caldeira \& Zorn, 42 Am. J. Pol. Sci. at 877; Murphy at 61 ("A Justice who persistently refuses to accommodate his views to those of his colleagues may come to be regarded as an obstructionist. A Justice whose dissents become levers for legislative or administrative action reversing judicial policies may come to be regarded as disloyal to the bench. It is possible that either appraisal would curtail his influence with his associates.")

${ }^{341}$ During this period, justices were authorized to employ a law clerk and a secretary. Pierce Butler used each to perform the duties of a law clerk, and one of them, John Cotter, wrote first drafts of most of Butler's opinions. The other justices, however, tended to employ only one law clerk, and to do their own drafting. See Barry Cushman, The Clerks of the Four Horsemen, Part I, 39 J. Sup. Ct. Hist. 386 (2014); Barry Cushman, The Clerks of the Four Horsemen, Part II, 40 J. Sup. Ct. Hist. 55 (2015); Melvin I. Urofsky, Louis D. Brandeis: A Life 465 (Pantheon, New York, 2009). Congress did not authorize the justices to hire two law clerks until 1941, though most of them continued to employ only one clerk until 1946. See Artemus Ward \& David L. Weiden, Sorcerer's Apprentices: 100 Years of Law Clerks at the United States Supreme Court 36-37 (N.Y.U., New York, 2006).

342 See Bradley J. Best, Law Clerks, Support Personnel, and the Decline of Consensual Norms of the United States Supreme Court, 1935-1995 at 214, 232 (L.F.B., New York, 2002) (finding "a positive, statistically significant relationship between the number of law clerks on the Court and the frequency of dissenting and concurring opinions"); Ley, Searles, \& Clayton, 49 Tulsa L. Rev. at 112-13, 121 (concluding that "the opportunity for cost-lowering effects of law clerks" is "significant to our understanding of the persistence of non-consensual norms"). 
addition of the Roosevelt appointees beginning in the 1937 Term, however, unanimity rates began a decline from which they would never recover: $69.7 \%$ for the 1937 Term; 64\% for the 1938 Term; 69.3\% for the 1939 Term; and $71.5 \%$ for Hughes's last Term as Chief Justice. And after Hughes departed the bench, it would be the exceedingly rare Term that would produce a unanimity rate exceeding $50 \%{ }^{343}$ The late Terms of the Hughes Court thus marked the death throes of a longstanding set of institutional norms and practices, and the inauguration of an era of "division and discord." 344

One might be tempted to think that the dearth of instances of acquiescence by the Roosevelt appointees is attributable to the fact that they so often found themselves in the conference majority. After Black replaced Van Devanter in August of 1937 and Reed succeeded Sutherland in late January of 1938, the "liberal" wing of the Court, earlier comprised by Justices Brandeis, Stone, and Cardozo, held a voting majority. As one observer put it in early February of 1938, "the President now controls the Supreme Court."'345 The subsequent additions of Frankfurter, Douglas, and Murphy served to solidify and augment that working majority. And it is true that, with the exceptions of Reed in Chambers and Perkins v. Elg, and the possible exception of Frankfurter in Falcone, the participating Roosevelt appointees were in the conference majorities of every major unanimous decision rendered by the late Hughes Court. In none of the remaining thirty-one unanimous cases was it necessary for a Roosevelt appointee to acquiesce in order to make a unanimous Court.

But when one examines the major cases in which unanimity was not achieved, a different picture emerges. Of the thirty-nine such

\footnotetext{
${ }^{343}$ Lee Epstein, Jeffrey A. Segal, Harold J. Spaeth, \& Thomas Walker, The Supreme Court Compendium: Data, Decisions, and Developments 247-49 (SAGE/CQ, Thousand Oaks, Cal., $5^{\text {th }}$ ed. 2012).

344 Melvin I. Urofsky, Division and Discord: The Supreme Court Under Stone and Vinson, 1941-1953 (Univ. of South Carolina, Columbia, S.C., 1997).

345 William E. Leuchtenburg, Franklin D. Roosevelt's Supreme Court "Packing" Plan, in Essays on the New Deal 74, 109 (Harold F. Hollingsworth \& William F. Holmes, eds., Univ. of Texas, Austin, Tex., 1969) (quoting Letter from Frank Gannett to E.A. Dodd (Feb. 5, 1938)). Due to the fact that Cardozo did not participate in any decisions after he became ill in December of 1937 , this majority was not consolidated until his replacement by Frankfurter in late January of 1939.
} 
cases in which Black participated, ${ }^{346}$ he joined the opinion of the Court in only twenty-seven (69.2\%). With the exception of Gobitis, in which he weakly acquiesced, Black was in the conference majority in each of these cases. ${ }^{347}$ As for the remaining cases, Black dissented whole or in part six, ${ }^{348}$ noted or wrote separate concurrences in four, ${ }^{349}$ and concurred in part and dissented in part in one. ${ }^{350}$ Reed recused himself from a number of cases with which he had been involved as Solicitor General, but he nevertheless participated in twenty-seven non-unanimous major cases..$^{351}$ of these he joined the opinion of the Court in twenty-two (81.5\%). In each of these cases he was in the conference majority. ${ }^{352}$ Of the remaining cases he dissented in three, ${ }^{353}$ concurred in one, ${ }^{354}$ and dissented in part and concurred in part in one. ${ }^{355}$ Frankfurter participated in seventeen such cases, and joined the majority opinion in fifteen (88.2\%). In each of these cases he was with the conference majority. ${ }^{356}$ In the remaining two cases, Frankfurter noted his concurrence. ${ }^{357}$ Douglas

${ }^{346}$ I exclude from this count Johnson $v$. Zerbst, which involved post-conference vote fluidity on the part of so many justices that it is difficult to analyze in terms of acquiescence and defection.

347 Palko; Nardone; Santa Cruz Fruit; New Negro Alliance; Lauf; Currin; Electric Bond \& Share; Bekins; Tennessee Electric; Erie; Mountain Producers; Gaines; Mulford; Eisenberg; Graves v. O'Keefe; Fainblatt; Schneider; Hood; Sunshine Anthracite Coal; Madden; Hague; O'Malley; Lane v. Wilson; Apex Hosiery; Rowan \& Nichols; Thornhill.

348 Connecticut General; Morgan II; Fansteel; Sands; Columbian Enameling; Classic.

${ }^{349}$ Carolene Products; Helvering v. Gerhardt; Rock Royal; Coleman.

${ }^{350}$ Consolidated Edison.

351 I exclude again from this number Johnson $v$. Zerbst, for the reasons stated in n. 346, supra. It is worth noting, however, that Reed did not ultimately join the opinion of the Court in Zerbst, but instead noted a concurrence.

352 New Negro Alliance; Currin; Bekins; Gaines; Mulford; Eisenberg; Graves v. O'Keefe; Fainblatt; Schneider; Hood; Sunshine Anthracite Coal; Rock Royal; Madden; Hague; O'Malley; Coleman v. Miller; Lane v. Wilson; Apex Hosiery; Rowan \& Nichols; Thornhill; Gobitis; Classic.

${ }^{353}$ Fansteel; Sands; Columbian Enameling.

${ }^{354}$ Erie.

${ }^{355}$ Consolidated Edison.

356 Mulford; Eisenberg; Fainblatt; Schneider; Hood; Sunshine Anthracite Coal;

Rock Royal; Madden; O'Malley; Lane v. Wilson; Apex Hosiery; Rowan \& Nichols; Thornhill; Gobitis; Classic.

357 O'Keefe; Coleman. 
participated in twelve such cases, and joined the Court majority in nine of them (75\%). In each of these cases he was in the conference majority. ${ }^{358} \mathrm{He}$ noted his concurrence in two others, ${ }^{359}$ and dissented in one. ${ }^{360}$ Murphy participated in five such cases, and joined the opinion of the Court in four of them $(80 \%)$. In each of these cases he was in the conference majority. ${ }^{361} \mathrm{He}$ dissented in the remaining case. ${ }^{362}$

Thus, with the lone exception of Black's weak acquiescence in Gobitis, of these thirty-nine non-unanimous major decisions in which one or more of the Roosevelt appointees participated, not a single one of the new justices changed his vote to join the majority between the conference vote and the final vote on the merits. Where they had cast dissenting votes in conference, they expressed their dissents in the U.S. Reports. And sometimes where they had voted with the majority on the judgment in conference, they would nevertheless note or publish a concurrence. As Professor David O'Brien has stated, unlike their liberal predecessors Holmes and Brandeis, Justices Black and Douglas, among others, "noted every dissent." 363

The docket books of the justices of the late Hughes Court thus help us to understand the reasons for the explosion of dissensus on the Stone Court. Some scholars have attributed the decline of unanimity during Stone's tenure principally to the Chief Justice's temperament and leadership style. Stone disdained false appearances of consensus, preferring instead the full airing of opinions both in conference and in the published reports. ${ }^{364}$ Others have agreed

${ }^{358}$ Schneider; Hood; Sunshine Anthracite Coal; Madden; O'Malley; Apex Hosiery; Rowan \& Nichols; Thornhill; Gobitis.

${ }^{359}$ Rock Royal; Coleman.

${ }^{360}$ Classic.

${ }^{361}$ Apex Hosiery; Rowan \& Nichols; Thornhill; Gobitis.

362 Classic.

${ }^{363} \mathrm{O}^{\prime}$ Brien, Institutional Norms, at 93. This is, of course, a bit of an exaggeration. See, e.g., Justice Black, Return of Warszower v. United States, 312 U.S. 342 (1941) ("I acquiesce"), and Justice Black, Return of Browder v. United States, 312 U.S. 335 (1941) ("I acquiesced"), Box 261, Hugo L. Black MSS, Manuscript Division, Library of Congress. The author of the circulated opinion in each case was Justice Reed.

${ }^{364}$ See, e.g., Walker, Epstein, \& Dixon, 50 J. Politics at 379-84; Danelski, The Influence of the Chief Justice, at 171-72, 175; Mason, Harlan Fiske Stone at 575, 591, 608. 
that these were significant factors, ${ }^{365}$ but have pointed to additional factors that may have helped to contribute to the decline. Among these are long-term changes in attitudes toward separate opinions; ${ }^{366}$ a proportional reduction in the size of the Court's nondiscretionary docket and changes in the types of cases composing that docket; ${ }^{367}$ and the influence of legal realism in emphasizing the indeterminacy of legal materials, exposing the grounding of legal principles in contestable social and political values, and in revealing fault lines in legal liberalism. ${ }^{368}$

Still other scholars, however, have observed that a change "in the propensity to dissent" appeared during the 1938 Term, "indicating that the Court's norm of consensus was first challenged by growing levels of dissent in the later years of the Hughes Court." ${ }^{\text {"369 }}$ This has inclined some to attribute the change in rates of dissent to the appointment of several new justices "who had not been socialized in the traditions of consensus," 370 to the fact that some of these justices who had formerly been law professors, who "are more likely to write separate opinions than Justices who began their careers in other professions," ${ }^{371}$ and to the strained interpersonal relationships among the justices. ${ }^{372}$ As Robert Steamer put it, the increase in dissensus was "a reflection of the fierce intellectual

365 Goldman at 337-39; Kelsh, 77 Wash. U. L. Q. at 178-79; Hendershot, Hurwitz, Lanier, \& Pacelle, Jr., 20 Political Research Quarterly at 9, 12; Robert J. Steamer, Chief Justice: Leadership and the Supreme Court 266 (Univ. of South Carolina, Columbia, S.C., 1986); Ley, Searles, \& Clayton, 49 Tulsa L. Rev. at 106; Pritchett at 40; O'Brien, Institutional Norms, at 99, 103; Corley, Steigerwalt, \& Ward, 38 J. Sup.

Ct. Hist. at 21, 27, 29-31, 32-35, 47.

366 Kelsh, 77 Wash. U. L. Q. at 175-80.

367 Goldman at 337; Hendershot, Hurwitz, Lanier, \& Pacelle, Jr., 20 Political Research Quarterly at 9, 13; Corley, Steigerwalt, \& Ward, $38 \mathrm{~J}$. Sup. Ct. Hist. at 2122, 27-28, 47. Cf. Walker, Epstein, \& Dixon, $50 \mathrm{~J}$. Politics at 364-70.

368 Ley, Searles, \& Clayton, 49 Tulsa L. Rev. at 106; O'Brien, Institutional Norms, at 101, 103; Corley, Steigerwalt, \& Ward, 38 J. Sup. Ct. Hist. at 21, 27-28, 47.

369 Hendershot, Hurwitz, Lanier, \& Pacelle, Jr., 20 Political Research Quarterly at 8.

370 Ley, Searles, \& Clayton, 49 Tulsa L. Rev. at 105; Goldman at 339. See also Corley, Steigerwalt, \& Ward, 38 J. Sup. Ct. Hist. at 22, 23-24; Walker, Epstein, \& Dixon, $50 \mathrm{~J}$. Politics at $378,385$.

${ }^{371}$ Ley, Searles, \& Clayton, 49 Tulsa L. Rev. at 122. See also Corley, Steigerwalt, \& Ward, $38 \mathrm{~J}$. Sup. Ct. Hist. at 22, 39-40; Walker, Epstein, \& Dixon, $50 \mathrm{~J}$. Politics at 385.

372 Goldman at 337; See also Corley, Steigerwalt, \& Ward, $38 \mathrm{~J}$. Sup. Ct. Hist. at 31-32; Walker, Epstein, \& Dixon, 50 J. Politics at 374. 
independence" of the members of the Stone Court, most of whom were also members of the late Hughes Court. "A spirit of compromise was only minimally present as each justice insisted on maintaining his own position." ${ }^{373}$ Thus, Professor O'Brien has noted that the decline in the Court's unanimity rate "began during the last four years of the Hughes Court, coinciding with the arrival of FDR's first five appointees (Black, Reed, Frankfurter, Douglas, and Murphy). During the 1933 to 1936 terms, when the Court's composition remained stable, the traditional norm of consensus prevailed. That norm, however, began to fail to hold in the last four years of Hughes's chief justiceship... ." ${ }^{374}$ Professor O'Brien therefore concludes that "too much weight has been given to [Stone's] influence and too little to the impact of changes brought by FDR's other eight appointees." 375

To see how the docket books help to illustrate this point, consider the following statistics. Of the seventy-two major cases that the late Hughes Court decided by full opinion, the final vote on the merits was unanimous in thirty $(41.7 \%)$. Had one or more of the Roosevelt appointees not acquiesced in the judgment of their colleagues, that number would have decreased only to twenty-seven (37.5\%) or twenty-eight (38.9\%), depending upon which account of Frankfurter's conduct in Falcone one credits. By contrast, had not one or more of the justices of the Old Court acquiesced, that number would have decreased to twelve (16.7\%).

A proper appreciation of the role of the Roosevelt appointees in increasing dissensus, therefore, simultaneously recognizes the corresponding contribution made by the late Hughes Court's senior members in retarding its public manifestation. Chief Justice Hughes, Justice McReynolds, and Justice Butler were together the justices responsible for the vast majority of instances of acquiescence on the late Hughes Court. When they left the bench, much of the long tradition of acquiescence left with them. With their departures, the Court was left with a number of members who would not yield to their colleagues. When they disagreed with another in conference, that division would appear in the published reports.

\footnotetext{
373 Steamer at 266.

${ }^{374} \mathrm{O}^{\prime}$ Brien, Institutional Norms, at 100-01.

375 O'Brien, Institutional Norms, at 103.
} 
A Court comprised by justices who shared greater ideological proximity could thus display higher rates of dissensus than had its more ideologically diverse predecessor. ${ }^{376}$ The seeds of public discord were sown by the appointment to the Court of justices who disdained the more compliant norms of their judicial forebears. Their full flowering was held at bay only by the continued observance of those norms by the last remnants of the Old Court.

376 The unanimity rates for the Stone Court were $60.9 \%$ for the 1941 Term, $49 \%$ for the 1942 Term, 38.5\% for the 1943 Term, 39.7\% for the 1944 Term, and $42.5 \%$ for the 1945 Term. Lee Epstein, Jeffrey A. Segal, Harold J. Spaeth, \& Thomas Walker, The Supreme Court Compendium: Data, Decisions, and Developments 225 (C.Q., Washington, D.C., $4^{\text {th }}$ ed. 2006). 